NOTICE: this is the author's version of a work that was accepted for publication in Sedimentary Geology. Changes resulting from the publishing process, such as peer review, editing, corrections, structural formatting, and other quality control mechanisms may not be reflected in this document. A definitive version was subsequently published in Sedimentary Geology, volume 383, 195-215 - doi: 10.1016/j.sedgeo.2019.01.009. (c) (2019) This manuscript version is made available under the CC_BY_NC_ND 4.0 license.

\title{
Palaeoenvironmental and tectonic significance of Miocene lacustrine and palustrine carbonates (Ait Kandoula Formation) in the Ouarzazate Foreland Basin, Morocco.
}

Sarah J. Boulton ${ }^{\star a}$, Justin H. VanDeVelde ${ }^{a, 1}$ and Stephen T. Grimes ${ }^{a}$

a School of Geography, Earth and Environmental Sciences, University of Plymouth, Drakes' Circus, Plymouth, PL4 8AA, UK

*Corresponding author: Sarah Boulton sarah.boulton@plymouth.ac.uk

${ }^{1}$ Present Address: University of California - Merced, 5200 North Lake Road, Merced, CA 95343, USA.

\begin{abstract}
The Ouarzazate Basin is the southern foreland basin to the High Atlas Mountains in Morocco. The sedimentary fill records a sequence dating from the Eocene to Pleistocene that records the interplay between tectonics and climate. This study presents the first stable isotope and facies analyses of the Middle to Late Miocene Aït Ibrirn lacustrine Member (Aït Kandoula Formation). These data test whether the basin was internally draining and enable the development of palaeoenvironmental models for the Middle to Late Miocene. Five sedimentary facies of lacustrine and
\end{abstract}


palustrine limestones are interbeddded with extensive sequences of palaeosols and fluvial sandstones and conglomerates, often associated with evaporite (gypsum) development. These facies can be divided into two facies associations related to water depth and sub-aerial exposure within the basin. In the Serravalian and early Tortonian shallow water successions dominate the stratigraphy, typical of underfilled foreland basin settings. Furthermore, carbonate $\delta^{18} \mathrm{O}$ and $\delta^{13} \mathrm{C}$ isotopes from the sections show covariance confirming that these carbonates were deposited within a hydrologically closed basin. However, late Tortonian to Messinian carbonates do not demonstrate the covariance typical of endorheic basins. Additionally, the facies association indicates the presence of deeper water lake systems demonstrating that the basin was externally draining at this time. These results question the established view of tectonic stagnation in the Late Miocene and suggest that the Cenozoic sediments of the Ouarzazate Basin contain a rich and untapped record of climate change and tectonic evolution on the edge of the Sahara desert.

Keywords: palustrine, lacustrine, terrestrial carbonates, stable isotopes, Morocco.

\section{Introduction}

Terrestrial carbonates have long been recognised as being excellent archives of climatic, environmental and tectonic information. Such carbonates can be found in extensional, compressional and cratonic settings and form in a wide variety of conditions from deep and shallow permanent lakes, palustrine conditions, to fluvially dominated plains. As a result the boundaries between different terrestrial sub- 
environments are not always clear (Alonso-Zarza, 2003) especially when there is no clear link between lake size, salinity, and climatic humidity (Herdendorf, 1984). This is especially true in semi-arid and arid environments where sub-aerial exposure and evaporation are common, which can result in pedogenic overprinting of previously deposited lacustrine carbonates forming the palustrine facies characteristic of seasonal wetlands (Platt and Wright, 1992; Wright and Platt, 1995). However, detailed sedimentology and petrography (i.e., Freytet and Verrecchia, 2002), combined with a robust stratigraphic framework (Bohacs et al., 2000) can allow the reconstruction of the morphology and type of palaeolakes. In addition, the geochemistry of primary carbonates can record the interplay between autogenic factors such as basin hydrology and biogenic productivity and allogenic effects of climate change, tectonics and drainage network evolution (i.e., Talbot, 1990; Talbot and Kelts, 1990; Valero-Garcés et al., 1995). Thus, providing records of terrestrial palaeoenvironmental changes that occurred through the evolution of lake systems.

In foreland basin settings, available accommodation space is controlled by the competition between subsidence, driven by loading, and uplift, resulting from thickening and rebound (DeCelles and Giles, 1996). While sediment supply reflects climate, uplift rate and river catchment size (Allen et al., 2013). Thus the balance between subsidence and sediment flux results in underfilling, filling or overfilling of the available accommodation space in the basin and is preserved in the sedimentary record through facies patterns and grainsize trends (i.e., Duller et al., 2010; Whittaker, 2011; Parsons et al., 2012). Therefore, lacustrine-palustrine wetlands in foreland basins can be sensitive recorders not only of palaeoenvironments within the basin but also reflect the uplift and erosion of the adjacent mountain front and the evolution of foreland basin drainage configurations. 


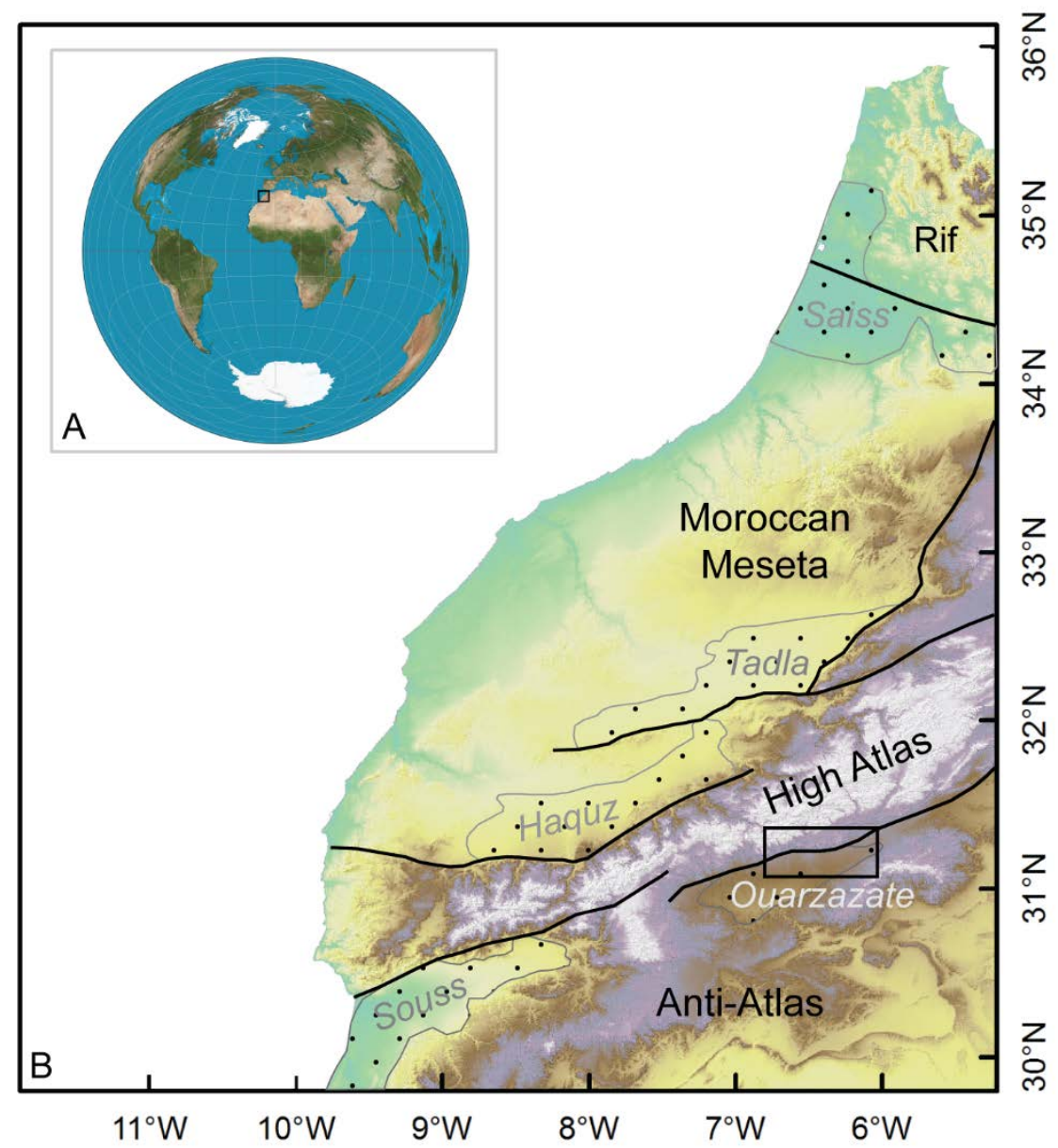

Figure 1. $30 \mathrm{~m}$ SRTM digital elevation model of Morocco showing the main tectonic units and Cenozoic sedimentary basins (grey text). Box indicates the location of figure 2. Globe inset shows the location of the DEM in Africa.

Here, Miocene limestones from the Ouarzazate Foreland Basin of Morocco (Fig. 1) are described using standard facies descriptions for the first time. In addition, the first stable isotope data from these sediments are presented challenging the long held hypothesis that the palustrine-lacustrine sediments were deposited entirely within a closed basin environment (Görler et al., 1988; El Harfi et al., 2001). These data not only provide new insights into the palaeoenvironments of the Ouarzazate Basin in the Middle to Late Miocene but also have implications for our understanding of the evolution of the adjacent High Atlas Mountains. 


\section{Geological Background and stratigraphic framework}

The High Atlas Mountains are $\mathrm{a} \sim \mathrm{W}-\mathrm{E}$ trending intracontinental mountain belt formed through the inversion of a Mesozoic rift system owing to N-S directed compression in the Cenozoic (e.g., Jacobshagen et al., 1988; Frizon de Lamotte, 2000). The South Atlas Fault (SAF) and the North Atlas Fault (NAF) form the southern and northern margins of the High Atlas, respectively (Fig. 1). The AntiAtlas Mountains to the south form the forebulge to the southern foreland basins. Mountain building is thought to have commenced in the Eocene, although the exact timing of deformation is still a matter of debate owing to the range of evidence used to investigate the development of the orogeny (Fig. 2). Some authors advocate multiple phases of uplift primarily based upon sedimentological observations (i.e., Görler et al., 1988; Frizon de Lamotte et al., 2000; El Harfi et al., 2001). While others propose continuous deformation from the Oligo-Miocene onward (i.e., Babault et al., 2008; Teson and Teixell, 2008; Balestrieri et al., 2009) based upon structural relationships and apatite fission track data.

South of the High Atlas, two foreland basins have developed during the Cenozoic as a result of lithospheric flexure in response to crustal loading (Beauchamp et al., 1999). These are the Souss Basin in the west and the Ouarzazate Basin in the east, separated by a topographic high of the Siroua Plateau (Fig. 1). The Ouarzazate Basin fill is $\sim 1 \mathrm{~km}$ thick, composed of Eocene to Quaternary alluvial, fluvial and lacustrine sediments (e.g., Fraissinet et al., 1988; Görler et al., 1988; El Harfi et al., 2001; Teson and Teixell, 2006; Teson et al., 2010). To the north of the Ouarzazate Basin, in the High-Atlas fold and thrust belt that forms the southern margin of the High Atlas Mountains, the Aït Kandoula and Aït Seddrat piggy-back basins also 
contain continental sequences (Fig. 3A). The syntectonic sediments deposited in these three basins preserve a key record of the evolution of the High Atlas system.

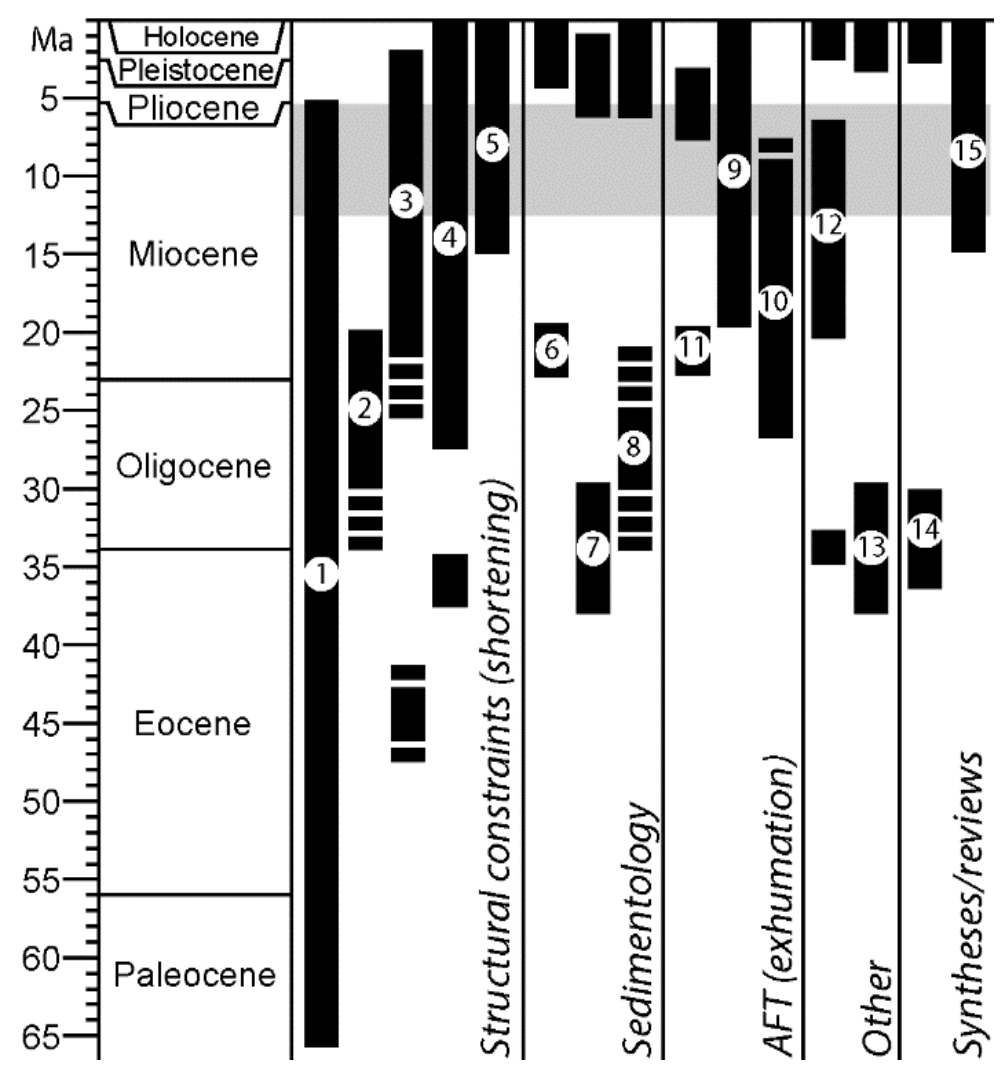

Figure 2. Timing of uplift of the High Atlas derived from different lines of evidence: 1) Faissinet et al. (1988); 2) Beauchamp et al (1999); 3) Teson \& Teixell (2008); 4) Teson et al. (2010); 5) Pastor et al. (2012); 6) Görler et al., (1998); 7) El Harfi et al. (2001; 2006); 8) Babault et al. (2008); 9) Barbero et al. (2007); 10) Missenard et al. (2008); 11) Balestrieri et al. (2009); 12) Missenard et al. (2006); 13)) Frizon de lamotte et al. (2000; 2009); 15) Gomez et al. (2000). Grey box indicates timespan of this study. AFT - Apatite Fission track.

Early studies by Görler et al. (1988) and Fraissinet et al. (1988) recognised in the Ouarzazate and Sub-Atlas basins two main Cenozoic units, the Hadida and Aït Kandoula formations, which were deposited unconformably over older stratigraphy. The Hadida Formation, was interpreted by Görler et al. (1988) as being deposited in proximal braided rivers and alluvial fans during the Early Oligocene to Early Miocene. While, the overlying Aït Kandoula Formation was subdivided into three lithostratigraphic units; an 'alluvial base member', the 'lacustrine member' and the 
'alluvial top member' loosely dated as being Early Miocene to Pliocene in age (Görler

et al., 1988). Görler et al. (1988) described the lacustrine member as being a

sequence of mudstones with various interbeds of conglomerates, limestones and

gypsum, which they interpreted as representing environmental changes between

freshwater lakes and perennial saline lakes in a hydrologically closed basin.

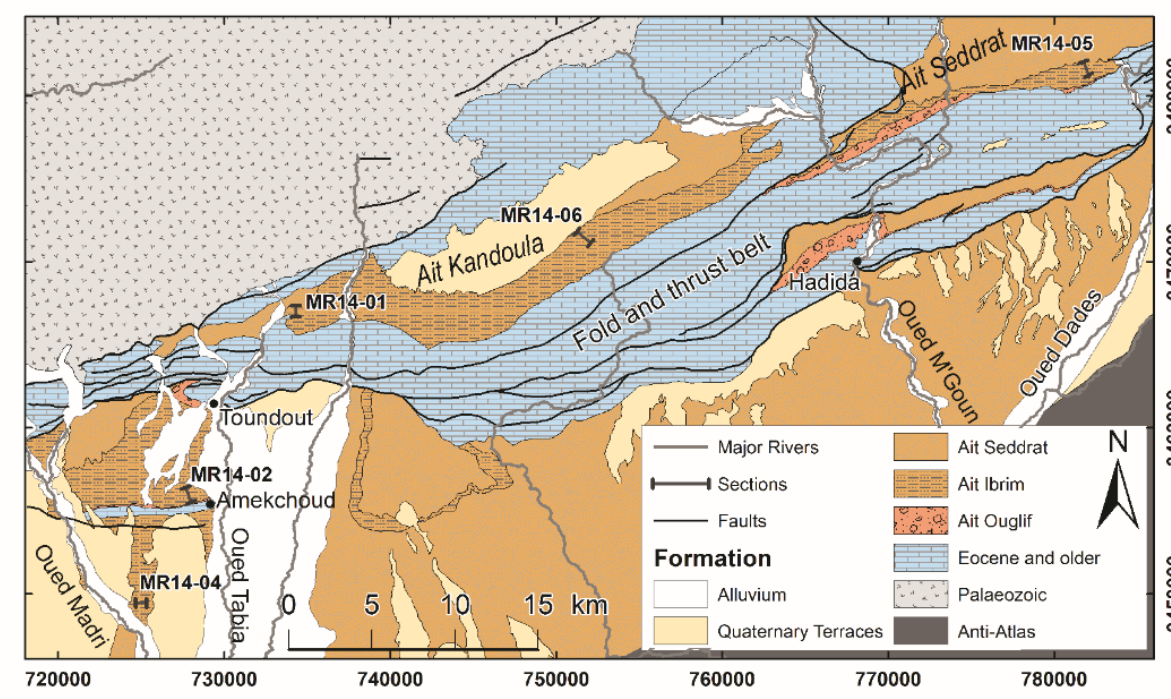

a.

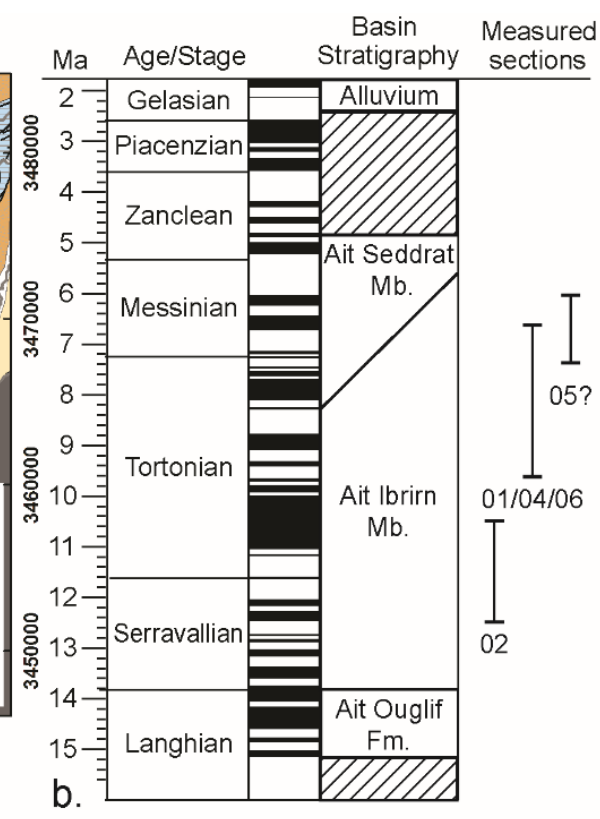

Figure 3 A) Geological map of the study area [modified from Teson and Teixell (2008) and Teson et al. (2010)], showing the location of the sections described herein. B) Inferred stratigraphic age and extent of the measured sections (01, 02 etc.) and lithostratigraphic units of the Ouarzazate basin (El Harfi et al., 2001; Teson et al., 2010) against the geological timescale and magnetic polarity of Gradstein et al., (2012).

However, issues with dating and lateral continuity of units led El Harfi et al. (2001) to formally (re)define the Cenozoic units of the Ouarzazate and Sub-Atlas basins. They described an Upper Eocene Hadida Formation and Aït Arbi Formation (previously the one formation), an Oligocene Aït Ouglif Formation (c.f., alluvial base member of Görler et al., 1988), and the Mio-Pliocene Aït Kandoula Formation. The Aït Kandoula Formation consisted of the previous 'lacustrine member' and 'alluvial top 
member', which El Harfi et al. (2001) recognised as unconformably overlying the Palaeogene stratigraphy. Teson and Teixell (2008) have subsequently formally subdivided the Aït Kandoula Formation into the lower Aït Ibrirn Member (lacustrine/palustrine environments) and the upper Aït Seddrat Member of alluvial fan conglomerates. Although El Harfi et al. (2001) and Teson and Teixell (2008) established a new stratigraphic framework (Fig. 3B) they did not substantially advance the sedimentology and palaeoenvironmental interpretation of the Aït Ibrirn member from that previously described by Görler et al. (1988).

Discoveries of mammalian fauna (Jaeger, 1977;; Görler et al., 1988; Benammi et al., 1995; 1996; Remy and Benammi, 2006; Zouhri et al., 2012), ash layers (Benammi et al., 1996) and magnetostratigraphic investigations in the Aït Kandoula (Benammi et al., 1996; Benammi and Jaeger, 2001) and Ouarzazate Basins (Teson et al., 2010) have continuously refined the dating of the Cenozoic sequence. The current age constraints suggest that the Hadida and Aït Arbi formations are likely Lutetian to Bartonian in age, the overlying Aït Ouglif Formation dates to the Langhian and the Aït Kandoula Formation was deposited during the Serravallian to Messinian (Fig. 3B; -13.5 - 5 Ma: Teson et al., 2010).

At the present, the lacustrine deposits in the Aït Kandoula and Aït Seddrat basins are located at higher topographic elevations than the locations sampled in the main Ouarzazate Basin (Fig. 3), yet structural analyses of the fold and thrust belt indicate that range front thrusting activated during the deposition of the Aït Ibrirn Member. (Teson \& Teixell, 2008). While tectonic deformation may have resulted in some compartmentalization of lacustrine depo-centres, it is not clear if there were substantial changes in elevation between lakes in different parts of the foreland basin system. The main phase of thrusting seems to have occurred during the 
deposition of the subsequent Aït Seddrat Member (Teson \& Teixell, 2008), leading to the suggestion that the lakes could have been connected prior to that time (Görler et al., 1998).

\section{Methods}

Field stratigraphic and petrographic observations of the Aït Ibrirn Member were accomplished by sedimentary logging of five key sections, which form a vertical transect through the member. Petrographic analysis of 28 thin sections from carbonate beds were used to identify carbonate microfacies based upon sedimentary, petrographic and textural features (Dunham, 1962; Flugel, 2004). These analyses were supplemented by staining of selected thin sections with Alizarin Red S and potassium ferricyanide to identify dolomite, and cathode luminescence was utilised to identify different phases of micrite formation. Cathode luminescence was undertaken at the University of Plymouth using a CITL cold cathode luminescence Mk5-2 microscope with operating conditions of $<10 \mathrm{kV}$ and $<$ $200 \mu \mathrm{A}$.

Carbonate microsamples ( $-300 \mathrm{ug})$ for isotopic analysis were collected from 114 slabbed and polished hand samples, using an electric drill under a binocular microscope. Sampling focused on the micritic matrix of each sample, avoiding diagenetic spar, intraclasts, and biogenic material, such as gastropod shells, to prevent difficulties in the interpretation of the isotope results due to alteration, transport, or biological factors. Microsamples were subsequently sealed in individual reaction vials, flushed with helium, and digested with phosphoric acid at $90^{\circ} \mathrm{C}$. Evolved $\mathrm{CO}_{2}$ was then analysed on a VG Optima isotope ratio mass spectrometer 
coupled to a Multiprep Automated Carbonate System at the University of Plymouth. Replicate analyses of NBS-19 and internal laboratory standards yielded precisions of $\pm 0.3 \%$ or better for $\delta^{13} \mathrm{C}$ and $\delta^{18} \mathrm{O}$. Both isotope ratios are reported relative to Vienna PeeDee Belemnite (VPDB).

\section{Stratigraphic correlation}

For this study, five representative sections of the Aït Ibrirn Member (Fig. 3) were selected owing to the existence of previous age constraints (sections $1,2,6$ ) or by being located nearby to previously described localities allowing an approximate stratigraphic correlation (Benammi et al., 1996; Benammi and Jaeger, 2001; Teson et al., 2010). In addition, the sections provide a vertical sequence through the Middle to Late Miocene and a lateral sequence west to east through the Ouarzazate, Aït Kandoula and Aït Seddrat Basins facilitating the evaluation of palaeoenvironmental trends in time and space.

Sections 2 and 4 are from the northern and southern limb of the Amekchoud anticline, respectively (Fig. 3A). Existing dating (Teson et al., 2010) of Section 2 allows us to assign an age to the section measured here as $\sim 12.5-10 \mathrm{Ma}$ (Fig. 3B). Section 4 has not been previously described and along strike correlations show that section 4 is stratigraphically higher than section 2 , suggesting a possible middle to late Tortonian age for this section. Sections 1 and 6 are located within the Aït Kandoula Basin (Fig. 3A) and form part of a continuous sequence of lacustrine sediments that span > $5 \mathrm{Ma}$ (Benammi et al., 1996). Section 6, located in the centre of the basin, correlates to part of Benammi et al.'s (1996) Afoud section that has been dated to the Tortonian and Messinian $(\sim 10-5 \mathrm{Ma})$. Whereas, section 1 is 
equivalent to Benammi et al.'s (1996) Oued Tabia section; therefore, this section is probably Tortonian in age $(\sim 10-7 \mathrm{Ma})$. Section 5 is located in the adjacent Aït Seddrat Basin; although no age constraints are available for this section, stratigraphic similarities to the Oued Tabia section suggests that this section could have also been deposited during the same time interval.

\section{Sedimentary Facies Analysis}

Fifteen sedimentary facies have been identified in the studied exposures. Summary sedimentary descriptions of the facies are given in Table 1, with facies abbreviations following convention with $\mathrm{G}$ for conglomerates, S for sandstones and $\mathrm{M}$ for mudstones and siltstones, and $\mathrm{L}$ for limestones.

\subsection{Carbonate facies field description}

In the field, the carbonate beds are lime mudstones or wackestones, rich in fragmentary bioclastic material and whole gastropods. Bed thickness is variable from

$1.0 \pm 0.2 \mathrm{~m}$ to $<0.1 \mathrm{~m}$ in thickness, the thinner beds are often laterally discontinuous, while bed boundaries are sharp and conformable. Sedimentary structures are generally rare but some horizons do exhibit wavy and undulating lamination and many beds have a rubbly texture.

\subsection{Carbonate microfacies analysis}

Five carbonate microfacies have been identified from detailed petrographic analysis of 18 samples taken from the logged sections, to give greater insight into the carbonate depositional environments. This analysis shows that mudstones are the most common microfacies (and are volumetrically underrepresented in the thin- 
section analysis as the coarser-grained samples were preferentially selected for further study), followed by wackestones with a variable bioclastic component. Microfacies have been characterised using Flugel's (2004) lacustrine microfacies (LMF) criteria. The majority of the samples show evidence for post-depositional pedogenic alteration consistent with palustrine environments.

\subsubsection{Lime Mudstones/fossiliferous micrite with pedogenic development (LMF1)}

This microfacies is composed of a dense micrite matrix exhibiting glaebule (i.e., irregular masses of secondary micrite) development with some circumgranular cracking around the incipient nodules. The primary micrite contains a small and variable bioclastic component composed primarily of fragmentary material, such as ostracods, bivalves and charophytes. Additionally, there are masses of prismatic sparite crystals likely to be Microcodium aggregates. This microfacies also contains a minor siliciclastic component composed of silt-sized $(<100 \mu \mathrm{m})$, sub-angular to sub-rounded, monocrystalline quartz grains of a detrital origin.

Porosity is variable and characterised either by irregular open pores or by lenticular (moldic porosity) holes. Microcrystalline spar and coarser sparite partially infills open porosity and some pore spaces have a gravity fill of micrite.

The original lime mudstone facies is indicative of deposition through settling from suspension, where the micrite likely originated from either cyanobacterial or algal blooms or from abrasion of limestones (Flugel, 2004). This facies is found in deeper protected parts of lacustrine systems as well as in shallower water areas. The samples studied here are typical of lacustrine carbonates that were affected by later pedogenesis and calichefication typical of palustrine environments. Circumgranular cracking occurs when the sediments are subjected to seasonal 
wetting and drying cycles, while the presence of Microcodium and irregular pore space indicates root activity within the sediment (Wright et al., 1995). By contrast, lenticular (moldic) porosity could indicate where evaporitic crystals have been removed, supported by the presence of rare rhombic zoned calcite crystals that are possibly pseudomorphs after dolomite or gypsum (Fig. 4A).

\subsubsection{Densely packed peloidal wackestone (LMF 5)}

This microfacies is composed of a nodular, peloidal micrite matrix with some recrystallisation to microspar. There is a detrital quartz component and fragmentary bioclasts of ostracods, gastropods, charophytes, and algal crusts. Sparite variably infills the original irregular porosity, rarely some infills have a lens of opaque minerals at the base forming a gravitational infill. As many of these infilled pore spaces have flat floors these can be described as fenestrae.

The presence of micrite peloids and fragmentary fossil material indicates that this facies was deposited as the result of current reworking in shallow water, probably near the lake shoreline. This is supported by the presence of fragmentary algal mat material that forms on the sediment surface within the photic zone (Freytet \& Verrecchia, 2002). Peloids are potentially also the result of reworking of primary precipitates or faecal pellets (Burne and Ferguson, 1983). The open-space structures maybe the result of subsequent bioturbation, sub-aerial dissolution (Flugel, 2004) or be part of the original algal mat structure. 

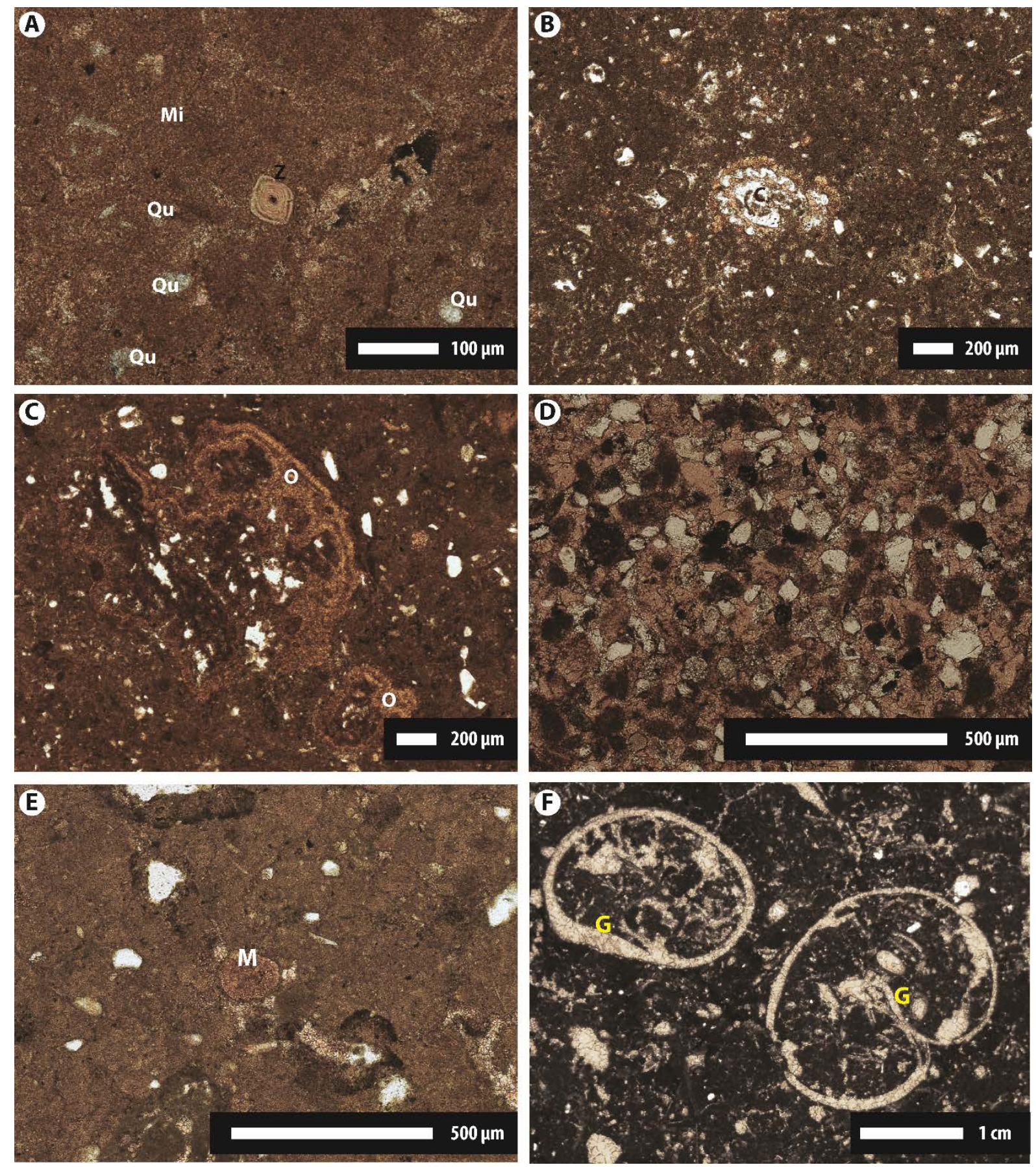

Figure 4. Photomicrographs of the main microfacies all in plane polarised light (PPL) except $A$ in cross-polarised light; a) lime mudstone ( $\mathrm{Mi}$ - micrite) with small quartz clasts (Qu) and zoned grains of calcite pseudomorphic after dolomite or gypsum (Z) from section $01 ; b)$ example of charophytic wackestone facies ( $C$ - charophyte) and $c$ ) encrusting algal nodule (oncolite $-O$ ) from 04; d) Siltstone with carbonate cement from section MR05; e) lime mudstone containing a spheroidal aggregate of Microcodium (M) and f) example of gastropod (G) wackestone from section MR06. 
5.2.3. Charophycean wackestones (LMF 7) with pedogenic development

This microfacies consists of a dense micritic matrix with variable nodule (glaebule) development with occasional circumgranular cracks beginning to form where nodule development is the most advanced (Fig. 5). There is minor recrystallisation to microspar but generally little sparite formation. Charophytes (Fig. 4B) form the most significant bioclastic component along with calcispheres (probably also charophytic in origin), fragmentary gastropods, ostracods and bivalves. In addition, laminar algal material (Fig. 4C) and Microcodium are present. There is a detrital siliciclastic component mainly composed of sub-angular to sub-rounded monocrystalline quartz grains (>80\%), but also polycrystalline quartz, opaque minerals and lithic fragments are variably present. In addition, there are rare zoned euhedral calcite crystals.

Charophytes are a type of green algal that inhabit freshwater and brackish environments and are highly characteristic of low energy, shallow water, lacustrine environments (i.e., Platt and Wright, 1991). Combined with the presence of ostracods and encrusting algal material this facies is characteristic of the shoreline region of many lakes (Flugel, 2004).

The primary sedimentary fabric is overprinted by secondary features characteristic of caliche development, including dense micrite/glaebules, intergranular cracking, and Microcodium aggregates, indicating subaerial exposure and pedogenesis after deposition. Microcodium are calcified root cells and indicate that root activity had an important role to play in the secondary alteration of these sediments (Wright et al., 1995). 

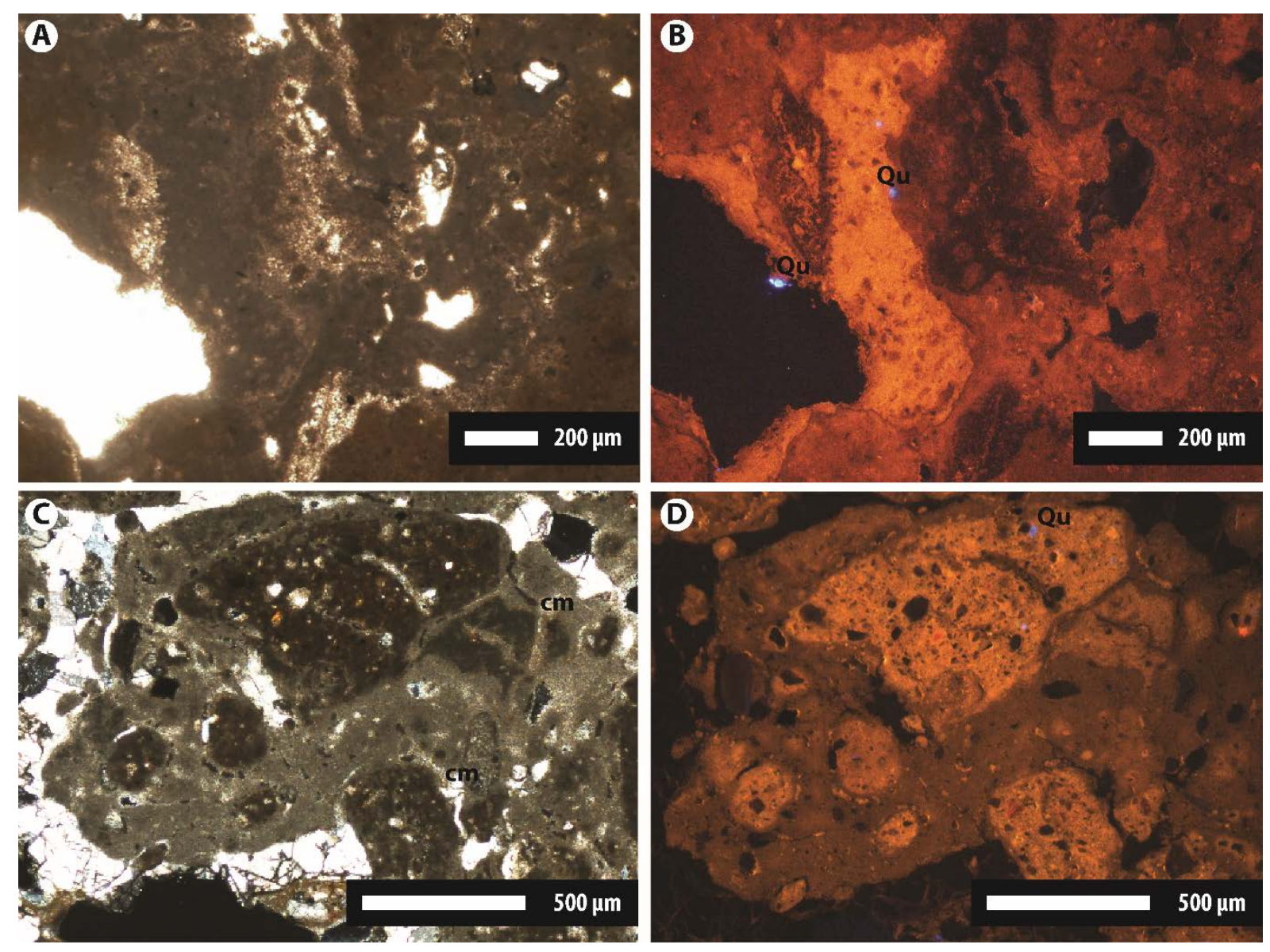

Figure 5. Comparison of PPL photomicrographs (left) and catholuminescence images (right) of sections 01 and 06. A) and B); Section 01 showing variable luminescence of micrite cement. Note quartz ( $Q u)$ grains with strong blue luminescence. $C$ ) and $D$ ) from 06 variable luminescence of glaebules with stronger (higher $\mathrm{Mg}+$ ) in core of the nodules and lower luminescence on the outer areas, also note circumgranular $(\mathrm{cm})$ crack development now infilled with sparite.

\subsubsection{Gastropod Wackestone and Packstone (LMF8)}

This microfacies is characterised by whole gastropods (Fig. 4F) and well-preserved charophytes (mostly oogonia but some stem material is also present), with fragmentary bioclastic material mostly derived from ostracods and bivalves/gastropods. There is some primary porosity in shell cavities but otherwise lacks other pore space in the micrite matrix, which is fairly texturally uniform but does contain rare silt-sized quartz grains. There is some recrystallisation of shelly 
material to sparite and some micrite to microspar. The micrite matrix also exhibits minor glaebule development with associated cracking in some areas.

The bioclastic component of this microfacies is consistent with shallow water lacustrine deposition and is similar to the Charophycean wackestone but with a much higher gastropod fauna suggesting more permanent water conditions (i.e., Burne and Ferguson, 1983).

\subsubsection{Carbonate cemented siltstone.}

This facies is a siltstone with $\sim 70 \%$ clasts and $30 \%$ cement (Fig. 4D). The clasts are either rounded micrite pellets or angular to sub-rounded lithic clasts dominated by monocrystalline quartz $(75-80 \%)$ and polycrystalline quartz $(\leq 16 \%)$ with minor opaque minerals (1-3\%). The cement is sparite, infilling the space around the grains, in places there are spar-filled areas with floating clasts resulting in a poikiliptic texture.

This facies is interpreted as the calcrete K-horizon. The sparite cement is consistent with alpha microfabrics dominated by non-biogenic features (Wright, 1990) characteristic of palaeosols in arid or semi-arid environments.

\subsection{Summary of carbonate facies}

The carbonate beds were deposited across a range of very shallow/intermittently inundated environments to slightly deeper water lake environments. The presence of abundant charophytic material is indicative of low-energy shallow water conditions 
(Platt and Wright, 1991; Flugel, 2004) and along with the presence of ostracods, is characteristic of freshwater or brackish environments. Slightly deeper water facies show evidence of the reworking of bioclastic material and the addition of allocthonous lithic and fine-grained organic matter. While shallow water facies are coarser-grained and contain material sourced from algal mats; seen in the field as irregular laminations. All carbonate facies have evidence of secondary nodule development, dissolution textures or root traces due to subaerial exposure and vegetation growth after deposition leading to the formation of typical palustrine limestone features.

\subsection{Siliciclastic and Sulphate Facies}

Grey to black mudstones and marls (facies $M$ and Ma) are generally massive but rarely can exhibit parallel lamination. Fragmentary fossil material is present, especially in the darker sediments. These very fine-grained sediments represent settling from suspension in lacustrine depocentres. The black mudstone indicates enrichment in organic carbon and possible low oxygen conditions within the waterbody.

Mottled Mudstones (facies Mp) are ubiquitous across the study area, with colour varying from a dark reddish brown through to light pink and grey and occasional blue and yellow mottling. Normally massive but with variable development of caliche and gypsum nodules. The tops of beds can exhibit root traces.

This facies is characteristic of soil development in semi-arid and arid environments. Mottling is likely the result of the remobilisation of Fe/Mn oxides/hydroxides due to 
oscillations in the water table (Freytet, 1973) resulting in wetting and desiccation (Alonoso-Zarza et al., 2012). While caliché formation is the result of carbonate leaching and precipitation within the soil profile (i.e., Wright, 1990; Goudie, 1996).

Planar laminated sandstones (facies Sp) are coarse-grained to very coarse-grained, grey litharenites. Beds are $<0.5 \mathrm{~m}$ thick with sharp bedding contacts and parallel laminations. This facies likely represents deposition within the upper flow regime owing to the coarse-grain size of the deposits coupled with laminations. Evidence for current flow suggests that these sandstones were deposited from a fluvial system.

Granular to pebbly sandstones (facies Sch) facies is composed of sub-rounded to well-rounded, poorly-sorted lithic clasts with a clast-supported texture. The bases of the beds are sharp and often erosional into lower strata, while the beds are laterally discontinuous over 10 s of metres. The morphology of these beds is highly suggestive of fluvial channels with a later sediment fill, possibly of small bar forms but no clear sedimentary structures were observed in the field.

Clast-supported conglomerates (facies Gc) are composed of sub-angular to subrounded, poorly-sorted lithic clasts with a clast-supported texture. Beds are massive with sharp bases and variable erosion into underlying sediments. This facies is characteristic of sheet floods, and could represent distal alluvial fan deposition.

Fibrous gypsum (Gf), beef or satin spar is composed of needle shaped crystals forming bedding parallel sheets up to a few centimetres in thickness, with the crystals orientated perpendicular to the bedding planes. This gypsum form is common in mudstone facies. This type of gypsum is a secondary precipitate from meteoric water. Growth of such bedding parallel veins is thought to relate to vein 
opening probably relating to dehydration of gypsum elsewhere in the basin or the effect of tectonic stress (Cobbold et al., 2013).
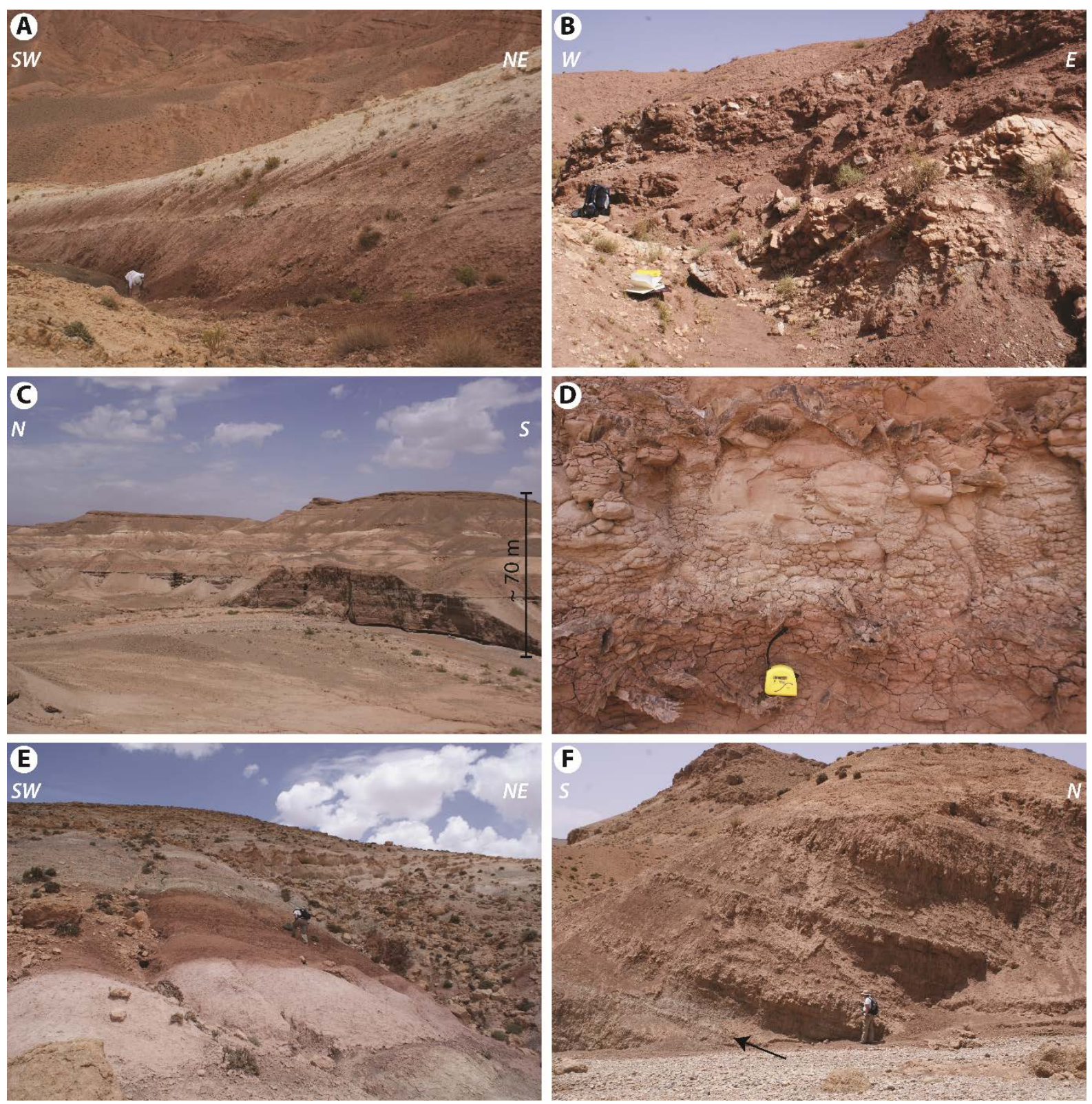

Figure 6a) Photograph of section 1 showing interbedded red mudstones and carbonates; b) Base of the section 2 showing first occurances of carbonates in the Aït Ibrirn Member. c) Overview of section 4 exposed due to Quaternary river incision, d) close up of matrix supported conglomerate formed of large selenite crystals in a mudstone matrix. e) Base of section 6 showing variation in mudstone colour and f) Palaeosols capped by well-developed caliche horizons in location 5. 
Selenite (Gy) crystals up to $30 \mathrm{~cm}$ in length occur as isolated crystals in mudstone facies or forming gypsiferous conglomerate (facies $\mathrm{Gg}$ ) with gypsum crystals randomly oriented within a lime mudstone matrix. Individual selenite crystals likely formed by upward growth from the sediment water interface in shallow water brine pools. The matrix-supported conglomerate likely represents reworking of such crystals potentially down slope in a debris flow.

A gypsarenite $(\mathrm{Sg})$ facies has been identified in a single location and is composed of sub-rounded, very fine to fine-grains of detrital gypsum. Bedding is massive. A lack of sedimentary structures makes it difficult to firmly establish depositional process beyond current reworking.

\section{Descriptions of studied sections}

\subsection{Section 1 - Oued Tabia}

Section 1 (Fig. 3) is located $5.7 \mathrm{~km} \mathrm{NE}$ of Toundout, exposed to the north of the road (UTM Zone 29N; 3466678 N 734459 W). The section unconformably overlies Paleogene limestones along a sharp, undulating boundary and is dominated by facies Mp (Figs. 6 \& 7A, Table 1) exhibiting various degrees of mottling and palaeosol development, with colour varying from light pink to dark reddish brown. At $11 \mathrm{~m}$ (Fig. 7A) the sediments become gypsiferous, and small gypsum crystals are present over the next $20 \mathrm{~m}$. By contrast, carbonate beds are rare in the bottom 50 $\mathrm{m}$ of the section and are generally laterally discontinuous over several metres and lack macrofossil material. However, carbonate becomes more frequent in the upper $50 \mathrm{~m}$ (Fig. 6A), forming laterally continuous, fossiliferous micrite with pedogenic development (LMF1) and variably intense bioturbation. Gastropods (e.g., 
Melanopsis sp., Hydrobia sp.,) are the most conspicuous and unfragmented macrofossils present. The top surface of many of the carbonate beds are rubbly with pseudo-karst development.

Towards the top of the section, palaeosol development is less intense and mudstones are not so mottled, indeed uniform grey mudstones and marls are interbedded with the carbonates in some horizons. Mottling reappears in the last 15 $\mathrm{m}$, where yellow, red, black mottling is present and effects mudstone and limestone beds. The dominantly fine-grained sediments conformably transition to the overlying conglomeratic unit at $\sim 105 \mathrm{~m}$ above the basal unconformity.
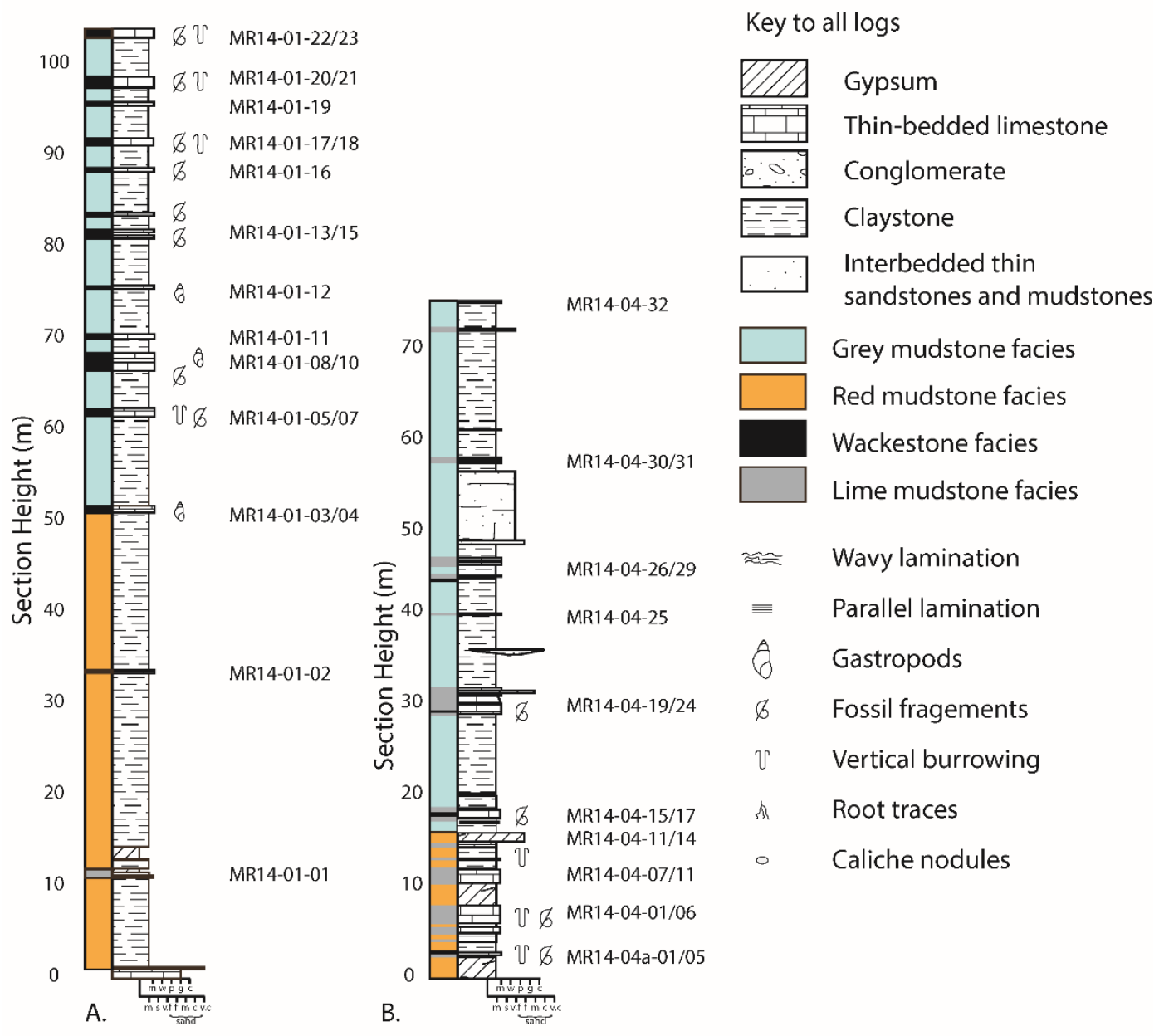

Figure 2 A. Sedimentary log of section 01 measured at Oued Tabia, B. Sedimentary log of the cliff section described from a tributary of the Oued Madri (section 04). Note position of sample numbers used for isotope geochemistry. For the location of the sections see figure 3. 


\subsection{Section 2 - Amekchoud}

Section 2 lies $\sim 1.5 \mathrm{~km}$ west of Amekchoud (Figs. 3 and 8), exposed in a series of wadis and associated badland topography, and correlates to part 1 of the Amekchoud profile sampled by Teson et al. (2010). At the base of the section beds dip at $55^{\circ}$ to the north, gradually decreasing to $35^{\circ}$ at the top of the section, the effect of the syn-sedimentary Amekchoud anticline to the south. The Aït Ibrirn Member conformably overlies the lower alluvial member (at UTM Zone 29N $3455692 \mathrm{~N}$ $727936 \mathrm{~W}$ ) and is recognised by the first appearance of gypsum with lenses of interbedded lime mudstone (Fig. 6B).

The basal sediments are heterolithic, with thin, $1-10 \mathrm{~cm}$ thick lime mudstone beds with equally thin red mudstone and fibrous gypsum beds (Fig. 8). Lime mudstones (LMF 1) exhibit well developed wavy lamination and fenestral porosity while the mudstones are massive. Upwards the section becomes dominated by thick, red mudstones, siltstones and muddy fine-grained litharenites. Occasional coarsegrained sandstone beds, $0.3-0.5 \mathrm{~m}$ in thickness, with planar lamination sometimes form individual horizons or the bases of fining-upwards packages, and thin carbonate and gypsum horizons continue to be present. The middle of the section is dominated by mudstone, gypsum and gypsiferous sandstone, including a $7 \mathrm{~m}$ thick, pure white sandstone formed of very fine grains of gypsum, capped by thin, laminated lime mudstones and wackestones (LMF5). At $318-338$ m, the section again becomes more heterolithic with grey mudstones interbedded between carbonate beds, $0.1-0.3 \mathrm{~m}$ thick, of LMF5. There is also the appearance of pebbly sandstones and laterally discontinuous conglomerate beds in the upper part of the measured section. Above this interval the unit again returns to red mudstones and sandstones with very minor to no carbonate. 

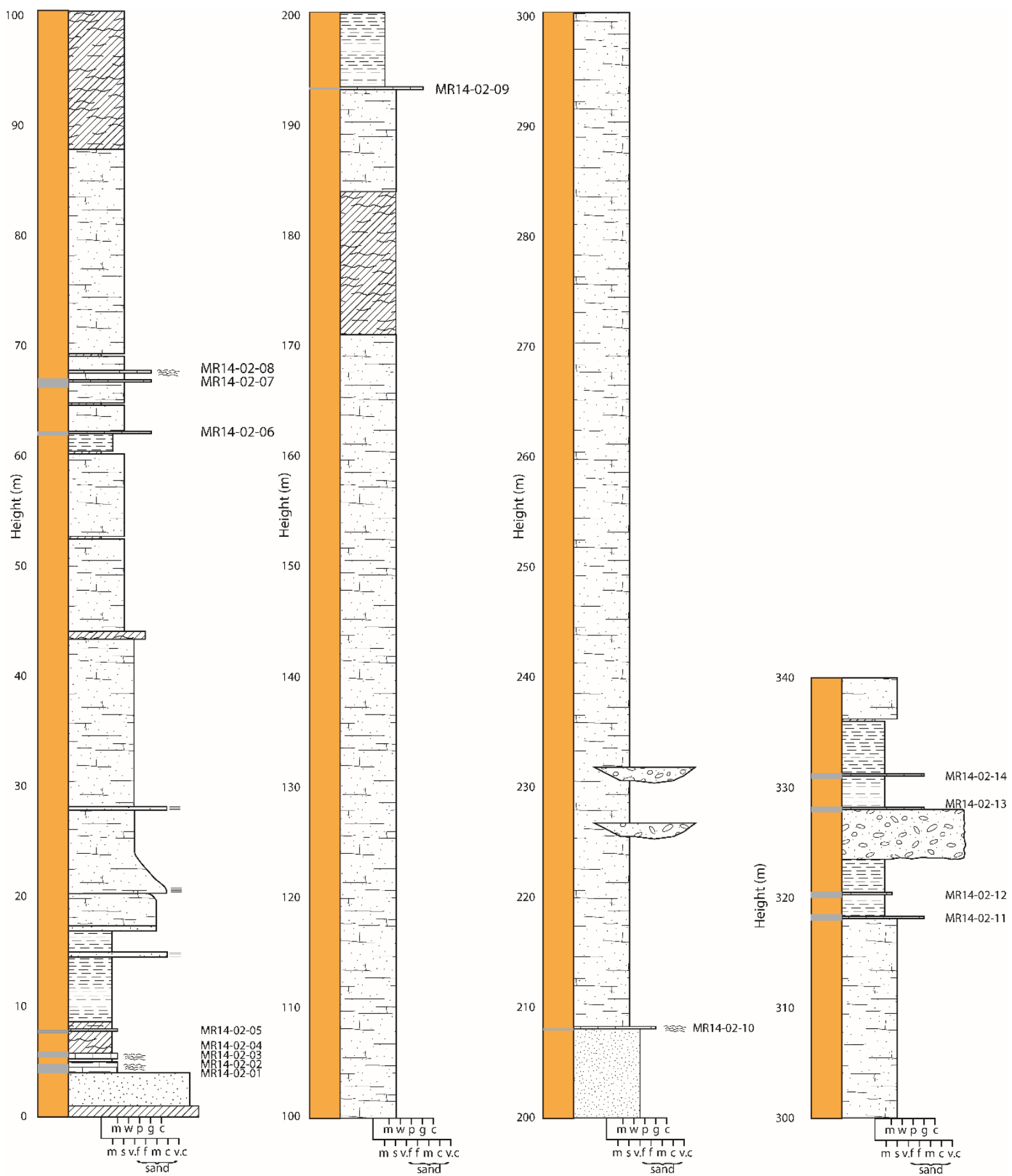

Figure 8. Sedimentary log of the Amekchoud section (Figure 3).

\subsection{Section 4 - Oued Madri tributary}

This section lies $3.5 \mathrm{~km}$ north of the small village of Aït Said O Mansour (Fig. 3), along a tributary of the River Madri (UTM Zone 29N 3449413N 725043W). The 
section is exposed in cliffs formed by the Quaternary incision of the river (Fig. 6C). Bedding is horizontal, lying on the southern limb of the Amekchoud anticline. The base of the member is not exposed in this location.

This section is characterised by much greater numbers of limestone beds than observed in other sections and by the presence of black mudstone horizons (Fig. 7B). The lower $20 \mathrm{~m}$ of the section is gypsiferous with large selenite crystals present forming discrete horizons. Especially of interest is a $0.6 \mathrm{~m}$ thick matrix-supported gypsum breccia, formed of shards of gypsum up to $0.3 \mathrm{~m}$ in length in a lime mudstone matrix (Fig. 6D). Elsewhere in the section gypsum is observed as occasional crystals located in the mudstone facies and becomes rarer up section; gypsum is not observed above $20 \mathrm{~m}$ in the measured section. Carbonate beds are lime mudstones (LMF1) or charophytic wackestones (LMF7) that exhibit variable amounts of vertical burrowing and often fine upwards from wackestone to mudstone but otherwise are lacking in other primary sedimentary structures. The beds are $0.05-0.3 \mathrm{~m}$ in thickness, but can form amalgamated bed sets of $>1 \mathrm{~m}$ thick. Many of the carbonate beds are immediately underlain by thin $(\mathrm{c} . \leq 5 \mathrm{~cm}$ ) horizons of dark grey to black, organic mudstones rich in microfossil material (e.g., ostracods, otoliths). The section consists of four packages of sediment that commence with the organic black mudstones then transition up into limestones followed by red sandy siltstones and mudstones with occasional coarser grained sandstone horizons.

\subsection{Section 05 - Oued Dades Valley, Aït Seddrat Basin}

This sequence is represented by a composite section from two localities $2 \mathrm{~km}$ apart along strike, it is noticeable that unit thickness is much reduced in this area at $\sim 60$ 
m. Here the Aït Ibrirn Member overlies only a thin veneer of the lower alluvial unit, which forms the lowermost fill of the Aït Seddrat basin in the Oued Dades valley. This section is dominantly composed of well-developed palaeosols (Figs. 6F \& 9) with rare individual beds of poorly developed lime mudstone, although bivalve and gastropod fossil fragments are observable in hand specimen. Calcareous litharenites (carbonate facies 5) cap the top of the well-developed palaeosol sequences. Grainsize increases upwards as cobble conglomerates appear in the section. The upper palaeosol beds are intensely mottled and exhibit well developed root structures and calcrete nodules.
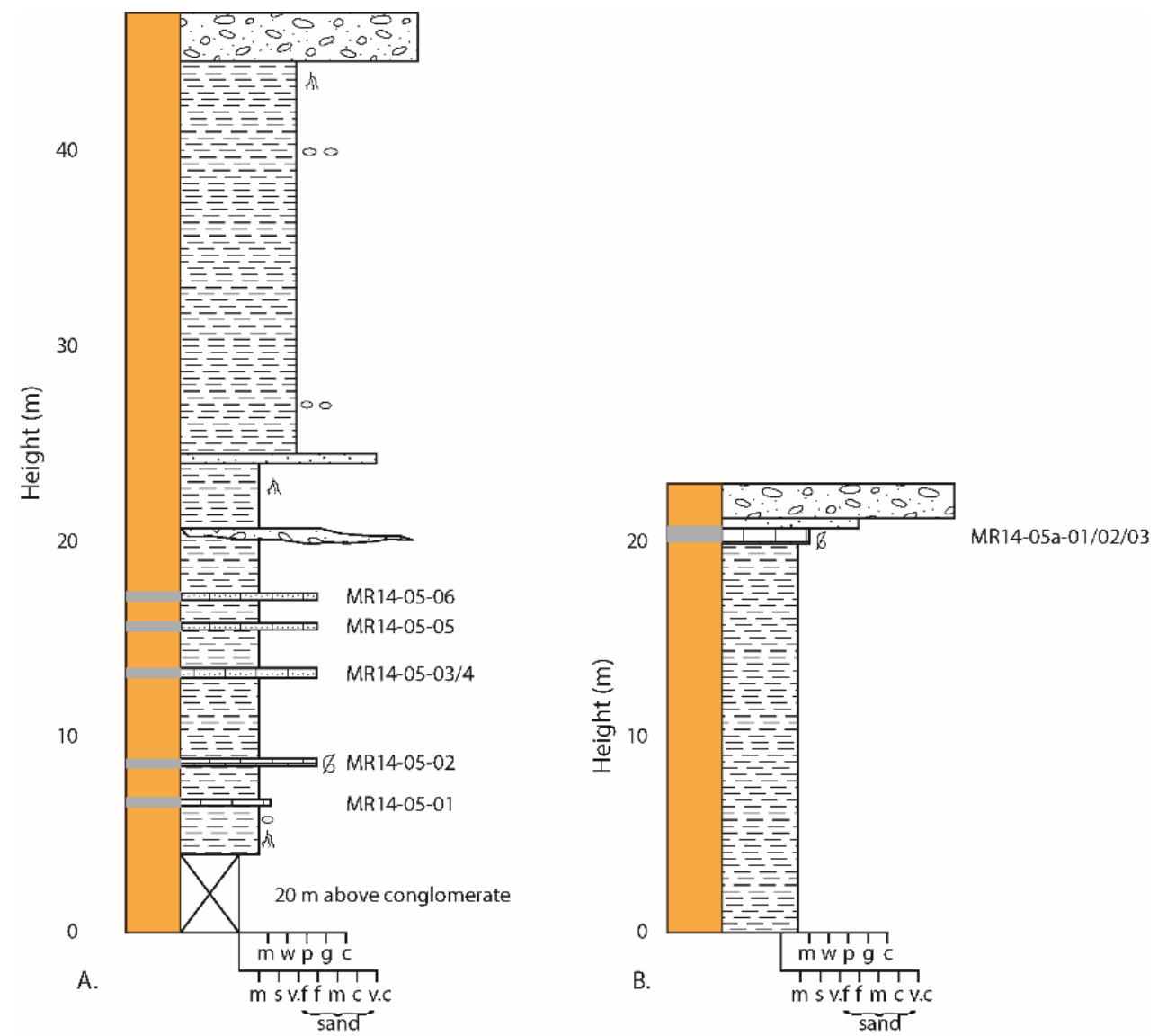

Figure 9. Sedimentary log from the Oued Dades region, section A (UTM Zone 29N, 3481286N $782241 \mathrm{~W}$ ) and B (UTM Zone 29N $3481002 \mathrm{~N} 781221 \mathrm{~W}$ ) are located $\sim 2 \mathrm{~km}$ apart along strike. The top conglomerate in section $A$ was traced along strike and section $B$ was measured above this horizon. 


\subsection{Section 06 - Afoud}
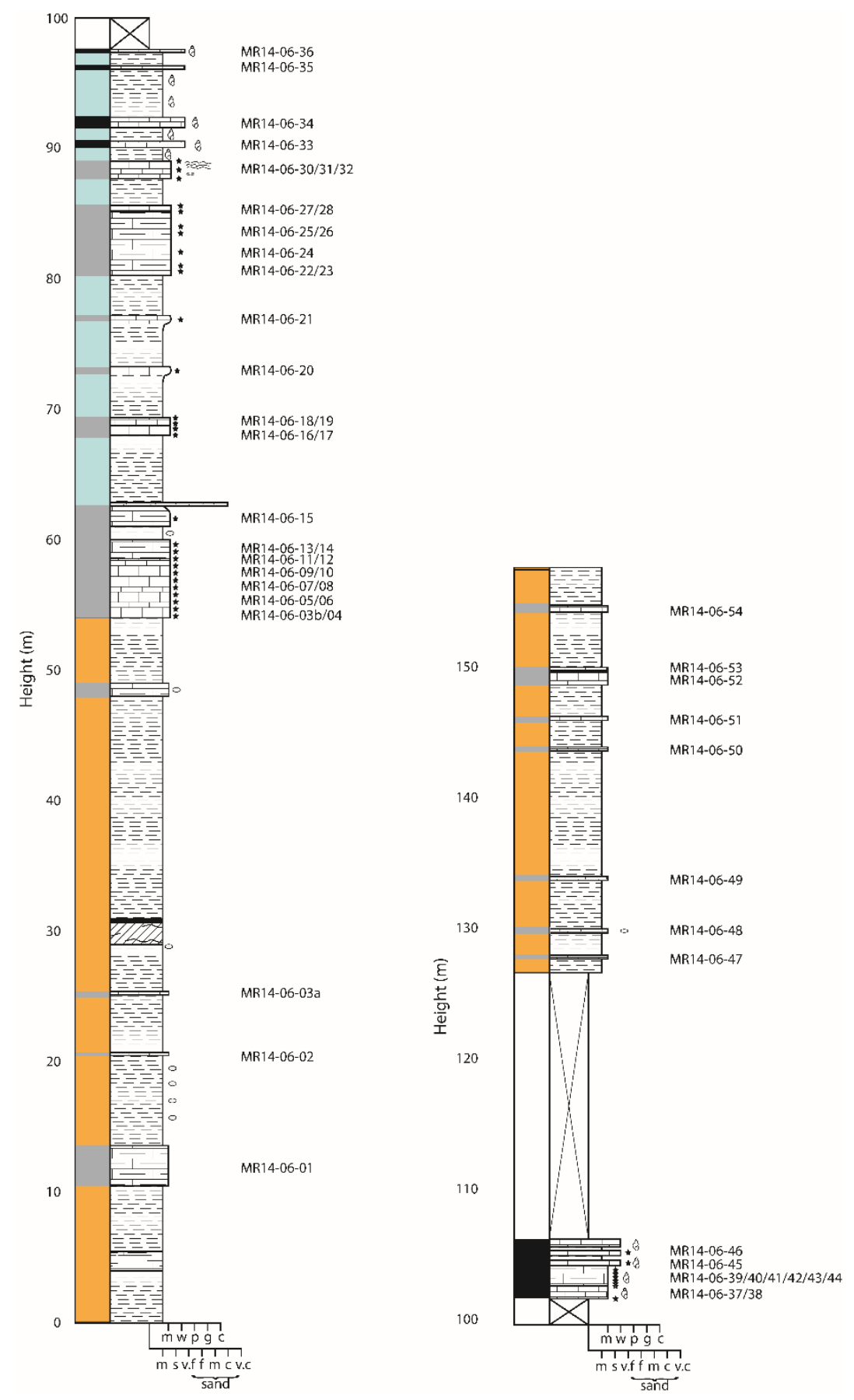

Figure 10. Sedimentary log of the Afoud section (06) in the Aït Kandoula Basin. Location of the section shown in figure 2.

The Afoud section was measured by Banammi et al. (1996), although their exact transect could not be established in the field we are confident that the section 
measured here (Fig. 3) is close to their AF7 location. This section is in the centre of the Aït Kandoula Basin (UTM Zone 29 N 3458548N 772547W).

The basal part of the section is composed of variably developed palaeosols capped by well-developed calcrete horizons (Figs. $6 \mathrm{E} \&$ 10). At $55 \mathrm{~m}$, thick beds of marly limestone and lime mudstone (LMF1) appear. These beds are nodular, have marly partings and often have rubbly tops. Limestone beds are interbedded mainly with grey mudstone and become thicker and coarser-grained up sequence (LMF1 and LFM8). Spar-filled voids (birds eye fenestrae) are common in the thicker beds. One $1.5 \mathrm{~m}$ thick bed is capped by $0.25 \mathrm{~m}$ of algal laminations. This $25 \mathrm{~m}$ part of the sequence is rich in gastropods, which are found in both the carbonate and interbedded grey mudstone beds. The upper part of the member returns to a red mudstone dominated sequence with isolated wackestone beds that occasionally contain birds-eye fenestrae before transitioning into conglomerates and sandstones of the overlying alluvial member.

\section{Facies Associations}

\subsection{Marginal, evaporative facies associations}

The dominance of mottled mudstone facies characteristic of palaeosol development with thin lime mudstones and presence of gypsum suggests that sections 2 (Amekchoud), 5 (Oued Dades) and the base of sections 1 (Oued Tabia) and 6 (Afoud), predominantly represent alluvial plain settings with periodic influence of shallow water, marginal lacustrine environments represented by the thin terrestrial carbonate horizons (Fig. 11). The abundance of subaerial features, root traces, 
mottling, etc., indicates that the wetlands were subjected to frequent emergence and pedogenic alteration. The mottling is indicative of water table fluctuations resulting in the migration of iron, manganese and calcium due to changes in the reduction potential of the sediment (Freytet and Verrecchia, 2002). High rates of evaporation and the presence of high-salinity water are also indicated by the presence of gypsum both as primary and reworked facies. The rare coarse-grained sandstones and channelised conglomerates observed at Amekchoud (section 2) may represent occasional deposition from active stream channels crossing the mudflats/plains. Furthermore, the carbonate beds are generally laterally continuous with little erosion evident in the sequence and are likely representative of shoreline deposition (Fig. 11A). This facies association is characteristic of the 'Evaporitive' lacustrine association of Carroll and Bohacs (1999) and Bohacs et al. (2000) and represents shallow water lake margin sedimentation.

\subsection{Deeper water carbonate lake facies association}

The sedimentology of the Oued Madri (Section 4) and upper Afoud (Section 6) sections still show abundant evidence of pedogenic modification, yet the limestone facies in these sections are thicker and more developed than observed in the marginal lacustrine facies associations. Charophyte material is abundant and suggests that the photic zone was relatively free of sediment (Dunagan and Turner, 2004), supported by the low amount of detrital quartz observed in thin section. Abundant bioclastic material and burrowing suggests also that the water bodies were normally oxygenated. Although the presence of evaporites in lower part of the Oued Madri section indicates that at times evaporation would have been high likely leading 
to salinity variations, also previously suggested by Görler et al. (1988). In addition, the presence of glaebule and intergranular cracking observed in thin section indicates that limestones were still affected by later pedogenesis and subaerial exposure (palustrine conditions).
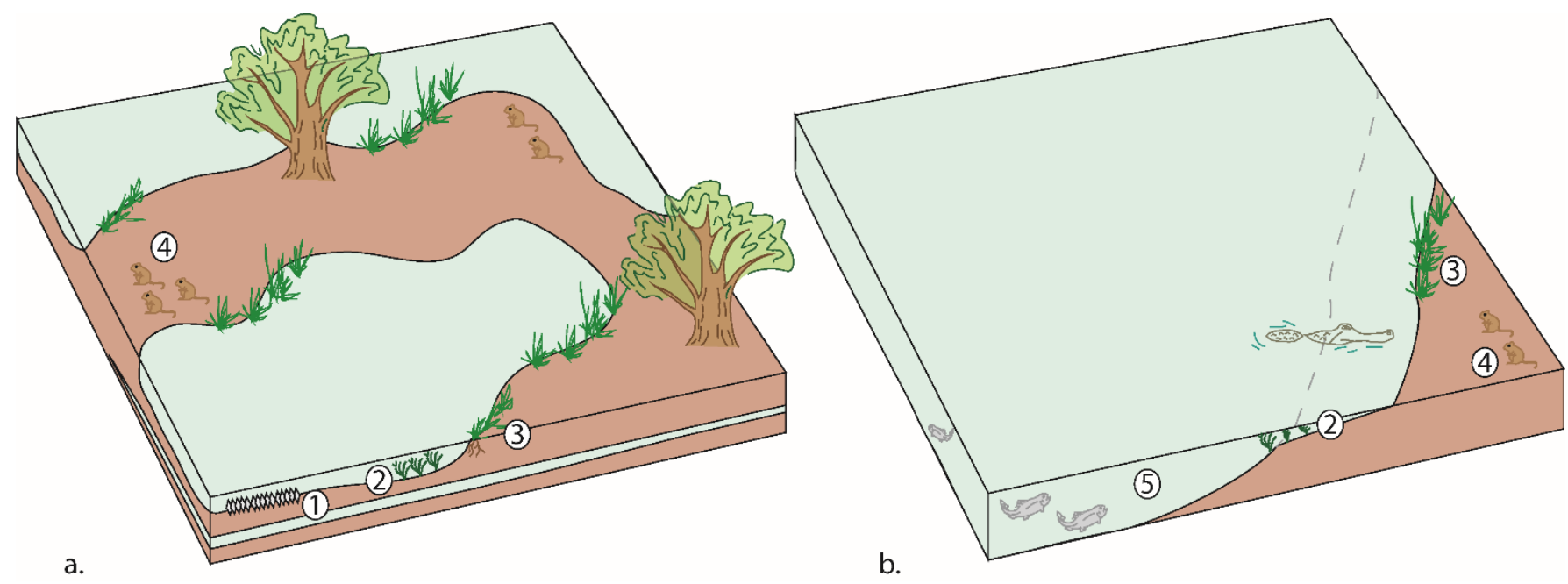

Figure 11. Conceptual models for the a) shallow water marginal environment and b) deeper water lacustrine facies associations of the Ouarzazate Basin; 1) mudstones with gypsum, 2) various wackestones, 3) pedogenic overprinting; 4) palaeosols (with a range of micromammal fossils e.g., Benammi et al., 2005; 2006) and 5) grey and black mudstones and lime mudstones with ostracod, bivalve and fish fossils.

The Oued Madri section in particular is interesting as there are defined sequences of organic rich mudstone, limestone, followed by mudstone plus or minus sandstones. These are interpreted as transgressive systems tracts (TST) and highstand sequences as described by Bohacs et al. (2000). Where the thin clastic beds are interpreted as sheet flows representing the rejunvenation of fluvial systems during the TST. These deposits are overlain by typical lake sediments, commonly enriched in organic material, recording the rapid inundation of a low relief surface. Peak organic enrichment has been recognised in many evaporitive lake systems just above the TST probably the result of an increase in primary productivity (i.e., Wilkins Peak Mb., Green River Formation., Bohacs, 1998), represented in this section by the 
thin black mudstone horizons. Overlying carbonate mudstones and wackestones represent deposition from suspension or reworking of material from the littoral zone during the maximum lake extent.

Therefore, these sections represent areas in the basin where more persistent lakes developed in the Tortonian (Fig. 11B), as indicated by facies associations and bed thicknesses. The marls likely represent the periods of more persistent and deeper water lacustrine conditions, while limestone beds reflect shallower water deposition. The presence of pedogenic features indicates that even in these areas desiccation and pedogenic alteration was common during lowstands.

\section{Stable Isotopes}

Alteration of primary depositional and pedogenic phases can be determined through petrographic and cathodluminescence microscopy. Non-luminescent cements and an abundance of vadose and subaerial exposure features are suggestive of carbonates that have undergone early diagenesis (Valero-Garcés and Aguilar, 1992). Analysis of samples shows mainly dull to moderate luminescence of the micrite with most variability related to glaebule formation (Fig. 5). Combined with a range of features related to subaerial exposure, suggests that these sediments underwent early diagenetic stabilisation and variable post-depositional alteration related to palustrine evolution.

Therefore, 120 bulk samples were drilled for stable isotope analysis from areas of micrite away from obvious areas of palustrine alteration. Lacustrine carbonates typically have depleted ratios of $\delta^{18} \mathrm{O}$ and $\delta^{13} \mathrm{C}$ when compared to marine 
carbonates (Keith and Weber, 1964), and the limestones of the Aït Ibrirn Member are no exception (Fig. 12).

Both sections 1 and 4 (Fig. 12) exhibit relatively constant isotope ratios, with no stratigraphically coherent shifts in either $\delta^{13} \mathrm{C}$ or $\delta^{18} \mathrm{O}$ (Fig. 12, Table 2). Carbon isotope ratios are similar in both sections (-6.0 $\pm 1.0 \%$ VPDB), while the average $\delta^{18} \mathrm{O}$ ratio is slightly lower in section $1(-8.1 \pm 0.5 \%$ VPDB) than section $4(-6.3 \pm$ 1.1\%o). Section 6 is somewhat more variable; a $\sim 3 \%$ negative shift in both $\delta^{13} \mathrm{C}$ and $\delta^{18} \mathrm{O}$ occurs over a $40 \mathrm{~m}$ interval in the middle of the section. The most negative values are associated with the deeper water lacustrine facies association. The overall isotope values $\left(\delta^{13} \mathrm{C}=-5.6 \pm 1.1 \%\right.$; $\delta^{18} \mathrm{O}=-5.8 \pm 2.1 \%$ ) are like those in sections 1 and 4 . Sections 2 and 5 also exhibit similar overall isotope values.

The isotopic composition of samples has also been considered by carbonate facies type at each location (Fig. 12), as not all samples were thin-sectioned this has been simplified into either lime mudstone or wackestone facies recognisable in hand specimen. In addition, the amount of palustrine alteration has been qualitatively assessed as either being low (no or negligible visible alteration) or present (obvious visible alteration in the hand specimen). Most specimens show some evidence for palustrine alteration apart from in section 6 , where little obvious alteration is present in some samples.

Section 2 is the oldest section dating to $-12.5-10 \mathrm{Ma}$ (Teson et al., 2010) with facies dominated by lime mudstone. These isotopic data plot in a single domain and have a clear covariant trend with an $r^{2}$ of 0.75 , and the regression line has a gradient of 0.79 (Fig. 12). 
Sections 4 and 6 date to $\sim 10-7$ and $9-6 \mathrm{Ma}$, respectively (Benammi et al., 1995; 1996; Benammi and Jaeger, 2001). These sections have the most extensive carbonate records and have more variable isotope ratios than the other sections sampled. Section 4, dominated by lime mudstone, exhibits variable $\delta^{18} \mathrm{O}$, while $\delta^{13} \mathrm{C}$ is somewhat less variable. Overall, the $\delta^{13} \mathrm{C}$ and $\delta^{18} \mathrm{O}$ show a weak co-variant trend with an $r^{2}$ value of 0.15 (Fig. 12).

Section 6 has the greatest sample density across wackestones, and low to clearly altered lime mudstones. When all data are plotted together there is a clear covariant trend with an $r^{2}=0.35$. However, when facies are plotted separately, the mudstone and wackestone facies do not plot in the same isotopic domain (Fig. 12). The wackestones have lower $\delta^{18} \mathrm{O}$ of -6.5 to $-8.5 \%$ in comparison to the majority of the lime mudstones that have $\delta^{18} \mathrm{O}$ as high as $-1 \%$, although $\delta^{13} \mathrm{C}$ values are comparable across all samples. Furthermore, the covariant trend is steeper and has an $r^{2}$ of 0.33 for the wackestones, although the origin of the covariant trend appears consistent with the mudstones in the lower part of the section. The lime mudstone facies can be split further into low and present palustrine alteration, and between the lower (below $55 \mathrm{~m}$ ) and upper (above $120 \mathrm{~m}$ ) parts of the section. Below $55 \mathrm{~m}$ lime mudstones with both little and clear pedogenic alteration have been analysed, both populations of data sit in the same domain and show a clear covariant trend. However, the $r^{2}$ values of the two data sets is different with the clearly altered sediments having an $r^{2}$ of 0.79 and the low alteration set $a r^{2}$ of 0.92 . This observation is an indication that palustrine alteration increases the scatter on the $\delta^{13} \mathrm{C}$ values in particular; similar observations have been made in the Miocene lacustrine systems of Spain that were also subjected to post-depositional pedogenesis (Arenas et al., 1997; Alonso-Zarza et al., 2012). By contrast, fewer 
carbonate beds are present above $120 \mathrm{~m}$ but these plot in a similar domain to the wackestones and the regression line has an $r^{2}$ value of 0.36 . Of note is that the slope of theis regression line $(0.26)$ is lower than for all the regressions on data lower in the sequence.

Sections 1 and 5 are the youngest studied intervals, and are thought to date to $\sim 9$ $5 \mathrm{Ma}$ (Benammi et al., 1996), although the age of section 5 is poorly constrained. Section 1 is dominated by gastropod-bearing wackestone with fewer lime mudstones than in the other sections; however, both facies plot in the same isotopic domain. When the two variables are cross-plotted, there is a weak covariant trend with an $\mathrm{r}^{2}$ of 0.13 when all isotope data for this location are taken into account (Fig. 12). By contrast, the isotopic analysis from section 5 shows little variance in either $\delta^{18} \mathrm{O}$ or $\delta^{13} \mathrm{C}$ with an $\mathrm{r}^{2}$ of 0.07 (Fig. 13). In addition, the data plot in a different isotope domain with lower $\delta^{13} \mathrm{C}(<4.5 \%$ ) than the other samples tested, although the slope of the regression line is 0.17 and therefore similar to sections 1,4 and the upper part of section 6 .

Figure 12 (next page). Stable isotope compositions of the micrite from sections 1 to 4 studied plotted by section height showing the vertical change in isotopic composition through the sections combined with isotope cross-plots for each section, facies association is indicted by colour where orange represents shallow water and blue represents deep water facies. Key to logs is shown on figure 7. Also included is a location map showing location of the Ouarzazate and Ait Kandoula Basins and approximate geological timescale. Isotope results are reported in standard delta-per-mil (\%) relative to PDB. 


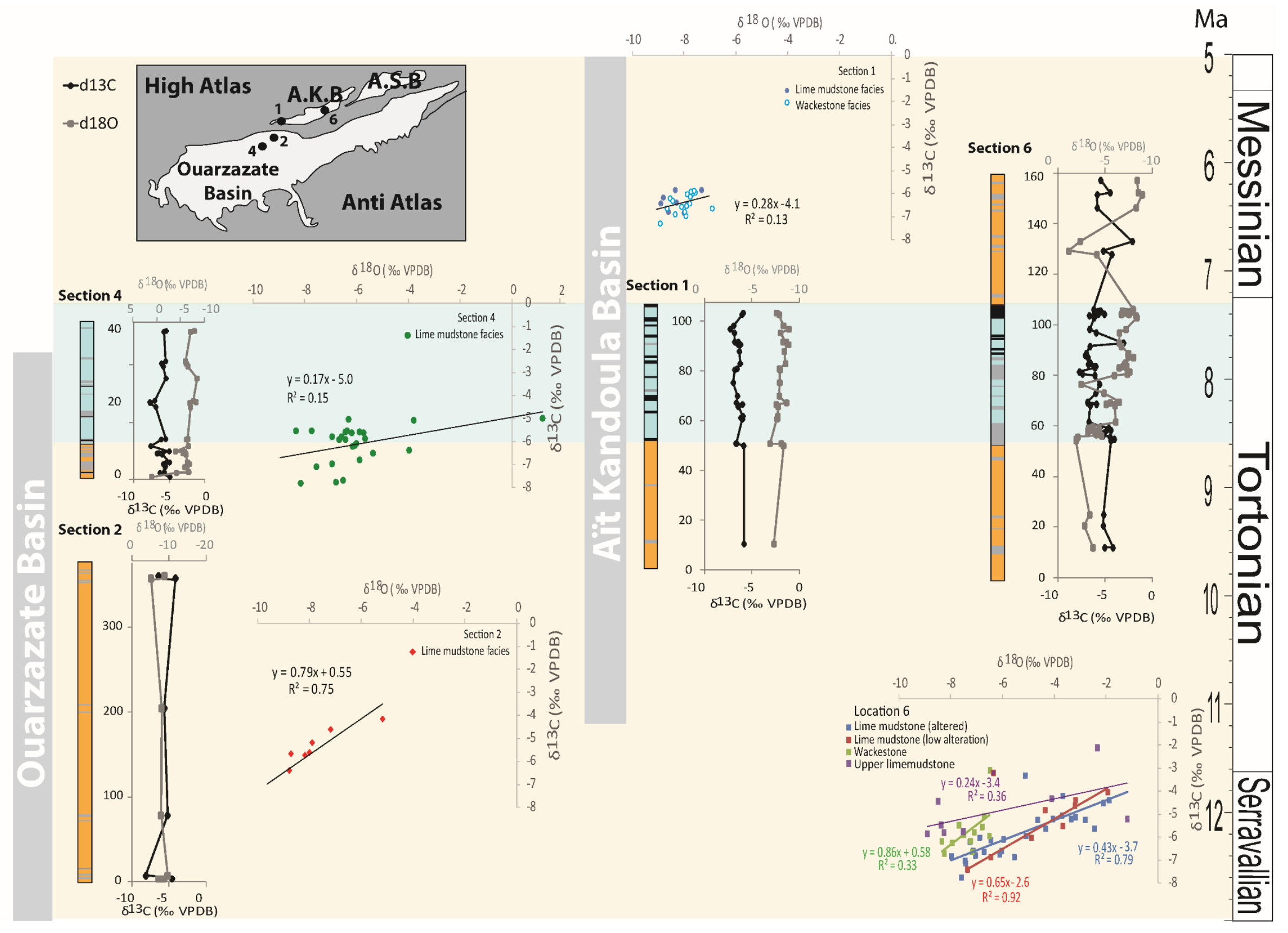




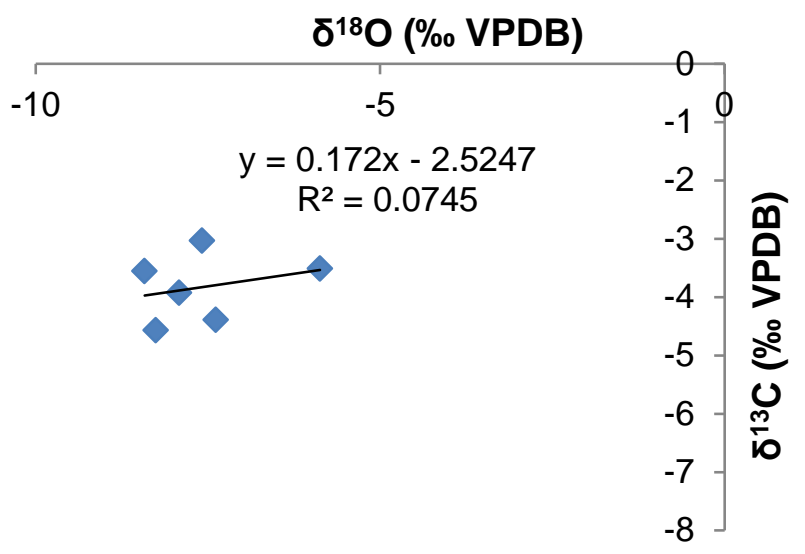

Figure 13. $\delta^{18} \mathrm{O} / \delta^{13} \mathrm{C}$ cross-plot of section 5.

\section{Discussion}

\subsection{Implications of isotopic variations laterally and vertically}

Section 2 is the oldest section studied ( 12.5 - $10 \mathrm{Ma}$; Teson et al., 2010), and is located in the main Ouarzazate Basin. The covariant trend with an $r^{2}$ of 0.75 (Fig. 12) is strong evidence that these carbonates were deposited in a hydrologically closed lake, as it has previously been demonstrated that strong positive correlations $\left(r^{2}>0.7\right)$ are characteristic of carbonate precipitation in closed lake environments (Talbot, 1990; Talbot and Kelts, 1990). This interpretation is supported by the presence of evaporites typical of such environments. Stratigraphically higher, section 4, represents the evolution of the Ouarzazate Basin lacustrine system. Although there is still a weak covariant trend the $r^{2}(=0.15)$ indicates a hydrologically open lake (Talbot, 1990). Yet a positive $\delta^{18} \mathrm{O}$ value indicates that there was either intense evaporation at the base of the section or that residence times were relatively long (Fig. 14), as hydrologically open lakes typically have only small variations in $\delta^{18} \mathrm{O}$ (Talbot, 1990). It is also possible that these basal sediments may still be 
recording a closed lake signal that progressively becomes more open up section, or that later pedogenesis has resulted in a loss of primary carbonate signatures resulting in lighter carbon values (Alonso-Zarza et al., 2012). Plant respiration promotes enrichment in ${ }^{12} \mathrm{C}$ in the substrate that can obscure the original isotopic trend (Dunagan and Driese, 1999; Tanner, 2000), yet Alonso-Zarza et al. (2012) demonstrated the pedogenesis does not completely obscure the original lacustrine isotopic signature. This conclusion is also supported by the data from section 6 studied here, where increased pedogenic alteration increases the data variability but does not obscure original trends. Therefore, we interpret that the Ouarzazate Basin lacustrine system evolved from a closed basin in the Serravalian to an open system in the Tortonian.

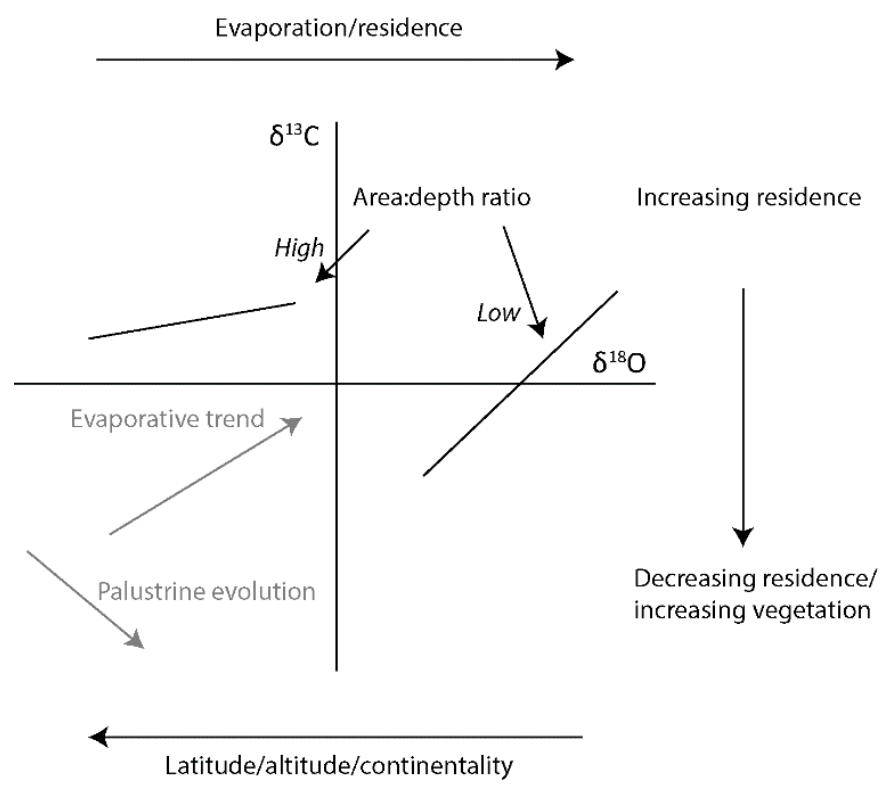

Figure 14. Summary of principal environmental controls on oxygen and carbon covariant trends in lacustrine sediments (modified after Talbot, 1990; Arenas et al., 1997). Increasing evaporation or residence time results in more positive $\delta^{18} \mathrm{O}$ values, whereas increasing latitude, altitude or continentality results in more negative $\delta^{18} \mathrm{O}$ values. By contrast, $\delta^{13} \mathrm{C}$ values become more positive in dry catchments and more negative in humid/well vegetated catchments. Post-depositional palustrine alteration of sediments will also move $\delta^{13} \mathrm{C}$ towards more negative values.

Interestingly, there is also a decrease in steepness of the regression line from s = 0.79 to $s=0.17$ from section 2 to section 4 , suggesting that the area/depth ratio of 
the lacustrine system had shifted (Fig. 14). It is unlikely that the lake became shallower over time given the sedimentary evidence of deeper water facies, instead we favour the interpretation that the area of the lakes became much greater at this time (Talbot, 1990). The origin of the covariant trends from the two sections is similar suggesting that the original isotopic compositions of the water masses feeding the lacustrine system was unaltered.

Section 6 is the same age as section 4 but located in the Aït Kandoula thrust top basin. There are sub-parallel trends between the isotopic value of the wackestones and lime mudstones, the slope of the two regression lines is 0.86 and 0.65 , respectively. However, the wackestones indicate an open lacustrine system as do the youngest lime mudstones above $110 \mathrm{~m}$ in the section $\left(r^{2}=0.33\right.$ and 0.36 , respectively). Whereas the older lime mudstones, showing less palustrine alteration, indicate a closed basin $\left(r^{2}=0.92\right)$.

In addition, there is a clear stratigraphic trend up section in both $\delta^{18} \mathrm{O}$ and $\delta^{13} \mathrm{C}$ (Fig. 12). At the $55 \mathrm{~m}$ level, where limestone beds become thicker and more common, values of $\delta^{18} \mathrm{O}$ and $\delta^{13} \mathrm{C}$ are high. The succeeding $50 \mathrm{~m}$ of deposition exhibit a coherent drop in $\delta^{18} \mathrm{O}$ and a smaller decrease in $\delta^{13} \mathrm{C}$. Extensive carbonate deposition ends at the $105 \mathrm{~m}$ level, with the few overlying thin carbonate beds exhibiting higher and more variable $\delta^{18} \mathrm{O}$. Taken with the physical sedimentology, extensive and thicker carbonates, change in mudstone colour and widespread gastropod shells from $\sim 90$ to $105 \mathrm{~m}$, the negative isotope shift in $\delta^{18} \mathrm{O}$ data suggests that the lake at section 6 was initially an evaporative and salty endorheic basin, which then progressively freshened through the late Miocene. The low $r^{2}$ values suggest that the lake became hydrologically open during the middle of the section. Similarly section 1 , along strike from section 6 , has low and stable values of $\delta^{18} \mathrm{O}$ 
and $\delta^{13} \mathrm{C}$ suggesting that evaporative drawdown was relatively limited at these sites during intervals of carbonate deposition. This suggestion implies that water residency times were short and the poor correlation of the covariance trend indicates that during deposition the lacustrine system was hydrologically open (Talbot, 1990). Furthermore, similar ranges in the $\delta^{18} \mathrm{O}$ and $\delta^{13} \mathrm{C}$ are seen across all four locations despite locations 1 and 6 being presently located in the Aït Kandoula thrust top and locations 2 and 4 in the Ouarzazate basin. This observation suggests that during the Miocene these different lakes formed part of a single hydrological system.

The age of section 5 is unclear as no age constraints have been published for the Aït Seddrat Basin. Samples for this area are from carbonates with significant pedogenic overprint, although data from elsewhere in the basin and Alonso-Zarza et al. (2012) demonstrate the original trends have been preserved. Therefore, our limited samples suggest deposition in an open lacustrine system and coeval deposition with the top of section 6 , suggesting that section 5 is of late Tortonian to Messinian in age based upon existing dating (Benammi et al., 1995; 1996). Also of note, is that the isotopes from section 5 sit in a different isotopic domain compared to the other sections. This observation can be explained as section 5 is located in the Aitt Seddrat thrust-top basin, to the east of the Aït Kandoula and Ouarzazate basin sediments, indicating the Aït Seddrat Basin was not connected to the rest of the lacustrine basins at this time.

These new isotope data show for the first time that the Miocene Ouarzazate lake system evolved from an initial hydrologically closed condition in the Serravallian to early Tortonian into an open lake system in the late Tortonian. 


\subsection{Miocene palaeoenvironments}

Late Serravalian to early Tortonian
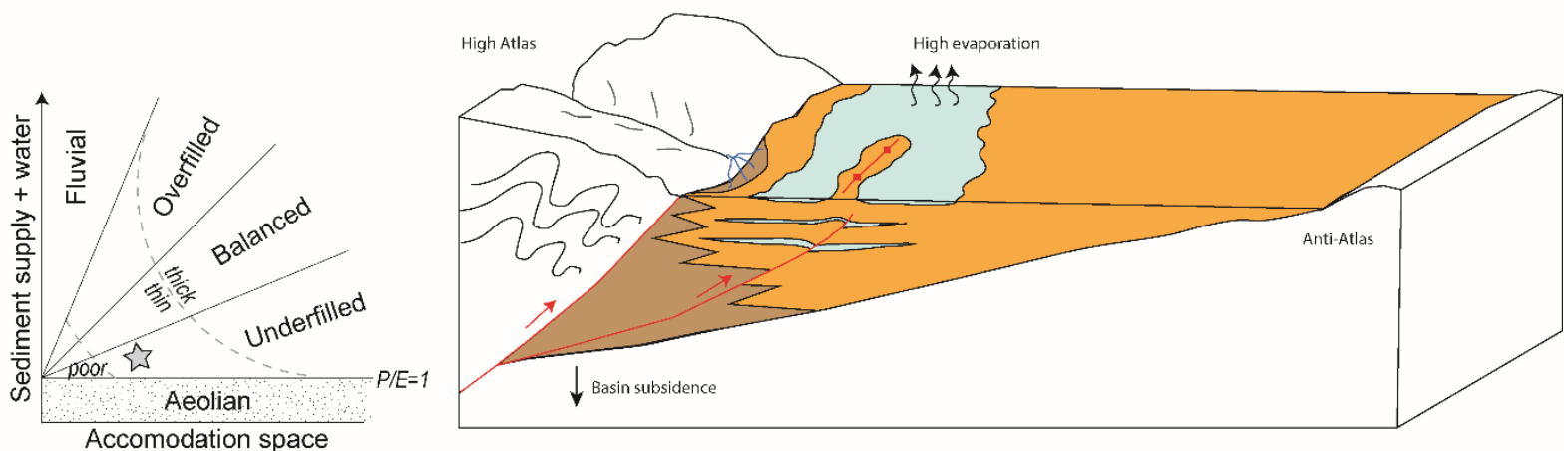

Tortonian
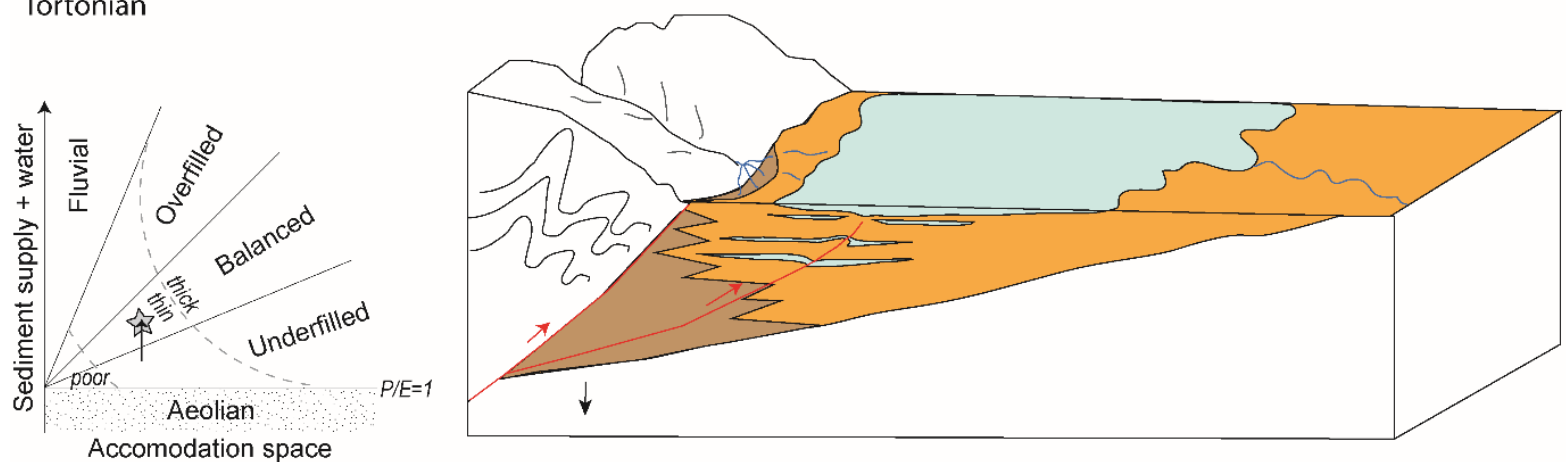

Figure 15. Palaeoenvironmental reconstructions for the Late Serravallian to early Tortonian showing underfilled basin conditions and the Tortonian with deeper and widespread lacustrine facies typical of a open lake. Inset graphs shows Caroll and Bohacs (1999) concept for lacustrine deposition with the approximate position of the lacustrine system at each time indicated by a star. Reducing accommodation space only, will not result in a change from underfilled to balanced filled lakes of any significant thickness; however, increasing sediment supply and water will result in this change.

The facies associations identified in the Middle Miocene sediments of the

Ouarzazate Basin fall into two groups, one indicating shallow, ephemeral lacustrine conditions typical of the 'evaporitive' facies of Carroll and Bohacs (1999) and the other more persistent and deeper water environments (Fig. 11). It is likely that the grey marls and overlying carbonate horizons indicate periods of highest water levels and freshest water in the basin. Combined with the stable isotope evidence, these data suggest that the Aït Ibrirn Member of the Ait Kandoula Formation was deposited in a lacustrine system that was initially hydrologically closed but over time became a hydrologically open system. 
Initial carbonate deposition started around $12.5 \mathrm{Ma}$, and is represented by section 2 and the base of sections 1,4 and 6 . The palaeolake system was possibly confined to smaller pools prone to evaporite deposition resulting in higher salinity water, with carbonate deposition taking place during highstands (Fig. 11A and 15). These ponds were surrounded by a playa of mudflats and marshes, where soil development overprinted older sediments resulting in the widespread palustrine facies observed. Pedogenic alteration would have been especially pronounced during lake level lowstands (Fig. 11A). Similar palustrine systems with fluctuating water levels have been described elsewhere in the Mediterranean during the Miocene (i.e., in Turkey; Alciçek \& Alciçek, 2014, and in Spain; Arenas and Pardo, 1999; Saez et al., 2007). Even though, lake levels were low there appears to have been limited transport of coarse alluvium into the basin in the areas studied. This lack of coarse sediment suggests that alluvial material was mainly being trapped in mountain front alluvial fans and that only sandy bedload and muddy suspended load was transported further out into the basin. Only occasional sheet floods and small channels transported coarse-grained material out into the foreland basin. As the Ouarzazate Basin was hydrologically closed at this time, it is reasonable to assume that high evaporation combined with low water input led to seasonal flow in the river systems and the termination of over ground flow in the remaining pools. These characteristics are typical of an underfilled lake basin (c.f., Caroll and Bohacs, 1999) where accommodation space exceeds sediment flux. As a result lake levels rarely reach sill levels and sediments are dominated by evaporite facies interbedded with alluvial-fluvial strata.

During the later Tortonian, it is likely that a lake covered a large portion of the Ouarzazate and Aït Kandoula Basins (indicated by El Harfi et al., 2001) (Fig 15). 
$\delta^{13} \mathrm{C}$ and $\delta^{18} \mathrm{O}$ values indicate that at these times the lake waters were variable in terms of oxygen levels and salinity but overall the system was hydrologically open and had transitioned into a 'balanced-fill' lacustrine system (Carroll and Bohacs, 1999). In balanced-fill lakes, accommodation approximately equals sediment supply and periodically surface outflows are developed.

Similarities in isotope measurements also suggest that the Ouarzazate and Aït Kandoula basins were connected. These persistent lacustrine systems resulted in thick carbonate beds and organic-rich mudstones rich in flora and fauna, interbedded with thicker sequences of massive, light grey mudstone and siltstone in the main depo-centres of the basin. The Oued Madri section exhibits five parasequences, each reflecting lake-level rise and subsequent fall, over $\sim 50 \mathrm{~m}$. These short term variations in lake level, and the changes observed across the wider basin between high and lowstands in lake level, are likely to be the result of changing water/sediment supplies determined by climate superimposed on tectonic subsidence creating the accommodation space in the basin.

The youngest sediments (uppermost section 6 and section 5) indicate that hydrological open conditions persisted into the Messinian. Although by that time it appears that the Aït Seddrat Basin was being fed by waters with a different isotopic signature and that a return to mainly fluvial deposition had taken place

\subsection{Climatic and tectonic influences}

Traditionally continental carbonates are thought to form when there is relative tectonic quiescence and when climate was neither too arid, nor too humid to prevent 
limestone formation (i.e., Cecil, 1990; Alonso-Zarza, 2003; Valero-Garcés et al., 2008; Pla-Pueyo et al., 2009; Valdeolmillos-Rodríguez et al., 2011; Cabaleri and Benavente, 2013; Ashley et al., 2014; de Wet et al., 2015). By contrast, the creation of tectonically induced relief has often been recognised in the rock record by the appearance of conglomerates (e.g., Heller et al., 1988; Flemings and Jordan, 1990; DeCelles et al., 1991; Carrapa and DeCelles, 2008). These ideas led El Harfi et al. (2001) to propose that the conglomerates preceding and following the lacustrine Aït Ibrirn Member were the result of pulses of surface uplift in the High Atlas shedding material into the Ouarzazate foreland Basin. It then follows that the intervening period of lacustrine deposition represents a period of tectonic quiescence in the building of the topography of the High Atlas Mountains (El Harfi et al., 2001).

However, other authors propose that tectonic activity in the High Atlas was continuous throughout the Miocene based upon structural relationships (i.e., Teson and Teixell, 2008) and fission track evidence of exhumation (i.e., Balestrieri et al., 2009) (Fig. 2). Indeed, the presence of underfilled (accommodation space > sediment supply) lacustrine deposits suggest high subsidence rates (Bohacs, 1999) incompatible with a model of total tectonic quiescence. High subsidence rates and tectonic activity have been shown to be essential for the formation of other lacustrine systems. For example, the deposition of the lacustrine Green River Formation (GRF) of North America is associated with periods of tectonism in the Eocene (Roehler, 1993; Pietras et al., 2003; Smith et al., 2015), not periods of inactivity.

Furthermore, facies models of non-marine foreland basins (e.g., Heller et al., 1988; Flemings and Jordan, 1990; Marr et al., 2000; Clevis et al., 2003; Densmore et al., 2007; Armitage et al., 2011; Allen et al., 2013) demonstrate facies retrogradation should occur when subsidence rates are high as a result of the increased 
lithospheric loading resulting from thrust emplacement. By contrast, phases of tectonic quiescence and erosional unloading cause the progradation of gravel facies across the basin and the displacement of longitudinal rivers distally away from the thrust front (Burbank, 1992; Burbank and Vergé, 1994).

If this is the case then high rates of subsidence during the Serravallian to Tortonian can account for the development of the lacustrine facies, while a Latest Miocene to Pliocene slowdown in thrusting, and reduction in load-induced subsidence, would explain the subsequent transition from the lacustrine sediments to the PlioQuaternary conglomerates . A cessation of thrusting in this period has previously been suggested (i.e., Faissinet et al.,1988; Balestrieri et al., 2009) prior to another phase of uplift in the Quaternary (Görler et al., 1998; El Harfi et al., 2001; 2006), associated with geomorphic evidence of landscape rejuvenation and gorge formation (i.e., Stokes et al., 2008, Boulton et al., 2014). Although, recent dating of fluvial terraces questions high rates of Quaternary uplift as incision rates are $<0.2 \mathrm{mmyr}^{-1}$ over the last $\sim 100 \mathrm{ka}$ (Stokes et al., 2018).

The Late Miocene lacustrine sediments record a change from closed to open hydrology through the Miocene with a concomitant increase in apparent water depth. This change in hydrodynamic conditions is likely the result of the breaching of a basin sill in the Late Tortonian due to the filling of available accommodation space and overtopping of the basin or owing to the capture of the basin by another drainage system.

Climatic forcing could drive the change from an underfilled to balanced fill system if accommodation space was constant, or increasing, and where sediment/water supply was also increasing (Fig. 13A). The presence of more persistent lakes argues 
for more water into the basin, potentially due the change from a semi-arid to subhumid climate supporting this argument. Higher lake levels could then have breached a local basin sill. A trend towards more negative oxygen isotope values in the Late Miocene sediments lends support to an increase in precipitation at this time.

However, the Middle - Late Miocene period is notable for global climatic shifts towards colder and drier climates (Potter and Szatmari, 2009) and in North Africa the Late Miocene is considered at the period when aridification of the Sahara developed (Schuster et al., 2006; Sepulchre et al., 2006). Neither of these trends would account for greater lacustrine activity at this time that would suggest wetter not drier conditions (Fig. 13 inset). Indeed Sepulchre et al. (2006) consider Early to Middle Miocene uplift key for developing the Atlas Mountains as a topographic barrier to moisture, and thus forming the Sahara Desert $\sim 8 \mathrm{Ma}$.

A decrease in accommodation space could also result in the filling of the basin and drive the trend in the sedimentary facies to a balanced fill system, despite the sedimentary evidence of more persistent lake facies (Fig. 15). Leprêtre et al. (2015) recently presented evidence for Middle Miocene uplift until $11 \mathrm{Ma}$, with subsequent cessation of loading. However, a reduction in accommodation space only (without any change to sediment/water input) would result in poor preservation of carbonate facies inconsistent with the sedimentary record. A reduction in subsidence would still need an increase in sediment supply to achieve a balanced-fill lacustrine system with preservation of sediments.

Finally, capture of the basin could also drive the observed changes in isotope composition. The Draa River is known to have captured the Dades River, which is the main drainage system of the Ouarzazate Basin, forming a $300 \mathrm{~m}$ deep canyon 
through the Anti-Atlas to the south. The timing of this event is not well constrained but is generally placed around the Pliocene - Pleistocene boundary, and has been ascribed to both regressive erosion of the Draa and basin overtopping (Stäblein, 1988; Arboleya et al., 2008). Arboleya et al. (2008) reported alluvial deposits of presumed Mio-Pliocene age resting on the crystalline basement of the Anti-Atlas adjacent to the Draa River supporting the overtopping hypothesis for the change from internal to external drainage.

Currently the temporal constraints on the sedimentary succession in the Ouarzazate Basin, the timing of thrust events and regional climatic trends are not well enough known to fully unravel the competing controls on basin sedimentation, but it is likely that higher rates of tectonic subsidence led to initial lacustrine deposition within the developing foreland basin. Over time the basin gradually filled up and possibly overtopped a sill, either due to the available accommodation space being exhausted or increased sediment/water supply. Headward erosion of the Draa River, or another palaeodrainage could also have captured the Ouarzazate Basin perhaps driven by periodic basin overtopping. While the ultimate mechanism for the changes between alluvial fan and lacustrine sedimentation and the change in lacustrine hydrodynamic conditions still needs further investigation, an explanation solely involving a tectonic hiatus during the Middle to Late Miocene is no longer satisfactory.

\section{Conclusions}

The sedimentary record of the Ouarzazate foreland basin provides valuable insights into the evolution of the adjacent intracontinental High Atlas Mountains. In this study, 
lacustrine sequences at five locations representing a temporal transect from the Middle to Late Miocene across the wider Ouarzazate Basin region were investigated. Facies descriptions, thin-section analysis, and carbon and oxygen isotope measurements were undertaken focussing on the carbonate beds of the Middle to Late Miocene Aït Kandoula Formation. Previous work by Benammi \& Jaeger (2001), Benammi et al. (1996) and Teson et al. (2010) provide the stratigraphic framework and age constraints for the sedimentology and geochemistry undertaken in this study. We demonstrate that these carbonates and palaeosols were indeed deposited initially in a hydrologically closed foreland basin, as proposed by El Harfi et al. (2001) and others but not previously unequivocally demonstrated. Furthermore, the facies associations of the Serravallian to Tortonian are characteristic of underfilled foreland basins with fluctuations between lacustrine highstands and lowstands driving much of the sedimentological variation observed in the sections. However, we also identify a previously unrecognised shift in the hydrodynamics of the lake system to hydrologically open conditions in the late Tortonian based upon carbon and oxygen isotope covariance and corresponding changes in the facies associations to persistent lake facies. While further research is needed, the evidence presented here indicates that these sediments were potentially deposited during a period of continued subsidence in the basin with superimposed climatic trends. This interpretation strongly suggests that this was not a period of tectonic quiescence but rather that tectonic loading and therefore active thrusting were ongoing throughout the Middle to Late Miocene. As such this formation records important evidence for the long-term continuous uplift of the High Atlas Mountains, with implications for geodynamic models of the evolution of this mountain chain and the wider western Mediterranean region. The fine-grained nature of the 
succession and ability to generate reliable magnetostratigraphic constraints on the timing of deposition also indicates that these rocks could also be an excellent, but as yet untapped, archive of Late Miocene climate change on the edge of the Sahara.

\section{Acknowledgements}

We thank the Royal Geographical Society with IGB for the award of the ThesigerOman Fellowship to SB, which funded this research. Funding for JvV was provided by the Natural Environment Research Council (NERC) NE/J020842/1. We also thank Martin Stokes and Jesse Zondervan for useful discussions that have improved the manuscript. In addition, we thank the editor (Brian Jones) and reviewer (Hülya Alçiçek) for further comments. The SRTM 1 arcs data product was retrieved from the online Data Pool, courtesy of the NASA Land Processes Distributed Active Archive Center (LP DAAC), USGS/Earth Resources Observation and Science (EROS) Center, Sioux Falls, South Dakota, https://lpdaac.usgs.gov/data access/data pool.

\section{References}

Alçiçek, H., Alçiçek, M.C., 2014. Palustrine carbonates and pedogenic calcretes in the Çal basin of SW Anatolia: Implications for the Plio-Pleistocene regional climatic pattern in the eastern Mediterranean. Catena, 112, 48-55.

Allen, P.A., Armitage, J.J., Carter, A., Duller, R.A., Michael, N.A., Sinclair, H.D., Whitchurch, A.L., Whittaker, A.C., 2013. The Qs problem: sediment volumetric balance of proximal foreland basin systems. Sedimentology, 60(1), 102-130. 
Alonso-Zarza, A.M., 2003. Palaeoenvironmental significance of palustrine carbonates and calcretes in the geological record. Earth Science Reviews, 60(3), 261-298.

Alonso-Zarza, A. M., Meléndez, A., Martín-García, R., Herrero, M. J., Martín-Pérez, A., 2012. Discriminating between tectonism and climate signatures in palustrine deposits: Lessons from the Miocene of the Teruel Graben, NE Spain, EarthScience Reviews. Elsevier, 113(3-4), 141-160.

Arboleya, M.-L., Babault, J., Owen, L. A., Teixell, S.,Finkel, R. C., 2008. Timing and nature of Quaternary fluvial incision in the Ouarzazate foreland basin, Morocco, Journal of the Geological Society, 165(6), 1059-1073.

Arenas, C., Pardo, G., 1999. Latest Oligocene-Late Miocene lacustrine systems of the north-central part of the Ebro Basin (Spain): sedimentary facies model and palaeogeographic synthesis. Palaeogeography, Palaeoclimatology, Palaeoecology, 151(1-3), 127-148.

Armitage, J. J., Duller, R. A., Whittaker, A. C., Allen, P. A., 2011. Transformation of tectonic and climatic signals from source to sedimentary archive. Nature Geoscience, 4(4), 231.

Ashley, G.M., Bunn, H.T., Delaney, J.S., Barboni, D., Domínguez-Rodrigo, M., Mabulla, A.Z., Gurtov, A.N., Baluyot, R., Beverly, E.J., Baquedano, E., 2014. Paleoclimatic and paleoenvironmental framework of FLK North archaeological site, Olduvai Gorge, Tanzania. Quaternary International, 322, 54-65.

Babault, J., Teixell, A., Arboleya, M. L., Charroud, M., 2008. A late Cenozoic age for long-wavelength surface uplift of the Atlas Mountains of Morocco. Terra Nova, 20(2), 102-107. 
Balestrieri, M. L., Moratti, G., Bigazzi, G., Algouti, A., 2009. Neogene exhumation of the Marrakech High Atlas (Morocco) recorded by apatite fission-track analysis. Terra Nova, 21(2), 75-82.

Barbero, L., Teixell, A., Arboleya, M. L., del Río, P., Reiners, P. W., Bougadir, B., 2007. 'Jurassic-to-present thermal history of the central High Atlas (Morocco) assessed by low-temperature thermochronology', Terra Nova, 19(1), 58-64.

Beauchamp, W., Allmendinger, R. W., Barazangi, M., Demnati, A., El Alji, M.,Dahmani, M., 1999. 'Inversion tectonics and the evolution of the High Atlas Mountains, Morocco, based on a geological-geophysical transect', Tectonics, 18(2), 163-184.

Benammi, M., Jaeger, J.-J., 2001. Magnetostratigraphy and palæontology of the continental Middle Miocene of the Aït Kandoula Basin, Morocco. Journal of African Earth Sciences, 33(2), 335-348.

Benammi, M., Orth, B., Vianey-Liaud, M., Chaimanee, Y., Suteethorn, V., Feraud, G., Hernandez, J., Jaeger, J.J., 1995. Micromammiferes et biochronologie des formations néogenes du flanc sud du Haut-Atlas Marocain: implications biogéographiques, stratigraphiques et tectoniques. Africa Geoscience Review, $2(2), .279-310$.

Benammi, M., Calvo, M., Prévot, M., Jaeger, J.-J., 1996. Magnetostratigraphy and paleontology of Aït Kandoula basin (High Atlas, Morocco) and the AfricanEuropean late Miocene terrestrial fauna exchanges. Earth and Planetary Science Letters, 145(1-4), 15-29.

Bohacs, K. M., 1998. Contrasting expressions of depositional sequences in mudrocks from marine to non marine environs. In: Schrieber, J., Zimmerle, W., 
Sethi, P.S., (Eds) Shales and Mudstones. Volume I, Basin studies, sedimentology, and paleontology. 33-78.

Bohacs, K.M., Carroll, A.R., Neal, J.E., Mankiewicz, P.J., 2000. Lake-basin type, source potential, and hydrocarbon character: an integrated sequencestratigraphic-geochemical framework. In: E. H. Gierlowski Kordesch and K. R. Kelts, (eds). Lake basins through space and time: AAPG Studies in Geology, 46, 3-34.

Boulton, S.J., Stokes, M., Mather, A.E., 2014. Transient fluvial incision as an indicator of active faulting and Plio-Quaternary uplift of the Moroccan High Atlas. Tectonophysics, 633, 16-33.

Burbank, D.W., 1992. Causes of recent Himalayan uplift deduced from deposited patterns in the Ganges basin. Nature, 357(6380), 680.

Burbank, D.W., Vergés, J., 1994. Reconstruction of topography and related depositional systems during active thrusting. Journal of Geophysical Research: Solid Earth, 99(B10), 20281-20297.

Burne, R.V., Ferguson, J., 1983. Contrasting marginal sediments of a seasonally flooded saline lake_Lake Eliza, South Australia: significance for oil shale genesis. BMR, Journal of Australian Geology and Geophysics, 8, 99-108.

Cabaleri, N.G., Benavente, C.A., 2013. Sedimentology and paleoenvironments of the Las Chacritas carbonate paleolake, Cañadón Asfalto Formation (Jurassic), Patagonia, Argentina. Sedimentary Geology, 284, 91-105.

Carrapa, B., DeCelles, P.G., 2008. Eocene exhumation and basin development in the Puna of northwestern Argentina. Tectonics, 27(1).

Carroll, A.R.,Bohacs, K.M., 1999. Stratigraphic classification of ancient lakes: Balancing tectonic and climatic controls. Geology, 27(2), 99-102. 
Cecil, C.B., 1990. Paleoclimate controls on stratigraphic repetition of chemical and siliciclastic rocks. Geology, 18(6), 533-536.

Clevis, Q., de Boer, P., Wachter, M., 2003. Numerical modelling of drainage basin evolution and three-dimensional alluvial fan stratigraphy. Sedimentary Geology, 163(1-2), 85-110.

Cobbold, P.R., Zanella, A., Rodrigues, N., Løseth, H., 2013. Bedding-parallel fibrous veins (beef and cone-in-cone): Worldwide occurrence and possible significance in terms of fluid overpressure, hydrocarbon generation and mineralization. Marine and Petroleum Geology, 43, 1-20.

DeCelles, P.G., Gray, M.B., Ridgway, K.D., Cole, R.B., Srivastava, P., Pequera, N., Pivnik, D.A., 1991. Kinematic history of a foreland uplift from Paleocene synorogenic conglomerate, Beartooth Range, Wyoming and Montana. Bulletin of the Geological Society of America, 103(11), 1458-1475.

Densmore, A.L., Ellis, M.A., Li, Y., Zhou, R., Hancock, G.S., Richardson, N., 2007. Active tectonics of the Beichuan and Pengguan faults at the eastern margin of the Tibetan Plateau. Tectonics, 26(4), TC4005.

de Wet, C.B., Godfrey, L., de Wet, A.P., 2015. Sedimentology and stable isotopes from a lacustrine-to-palustrine limestone deposited in an arid setting, climatic and tectonic factors: Miocene-Pliocene Opache Formation, Atacama Desert, Chile. Palaeogeography, Palaeoclimatology, Palaeoecology, 426, 46-67.

Duller, R.A., Whittaker, A.C., Fedele, J.J., Springett, J., Smithells, R., Allen, P.A., 2010. From grain size to tectonics. Journal of Geophysical Research - Earth Surface, 115, F03022. 
Dunagan, S.P., Driese, S.G., 1999. Control of terrestrial stabilization on Late Devonian palustrine carbonate deposition; Catskill Magnafacies, New York, USA. Journal of Sedimentary Research, 69(3), 772-783.

Dunagan, S.P., Turner, C.E., 2004. Regional paleohydrologic and paleoclimatic settings of wetland/lacustrine depositional systems in the Morrison Formation (Upper Jurassic), Western Interior, USA. Sedimentary Geology, 167(3), 269-296.

Dunham, R. J., 1962. Classification of carbonate rocks according to depositional textures: in Ham, W.E., ed., Classification of Carbonate Rocks. American Association of Petroleum Geologists, Memoir 1, 108-121.

El Harfi, A., Lang, J., Salomon, J., Chellai, E. H., 2001. Cenozoic sedimentary dynamics of the Ouarzazate foreland basin (central High Atlas Mountains, Morocco).International Journal of Earth Sciences, 90, 393-411.

El Harfi, A., Guiraud, M., Lang, J., 2006. Deep-rooted "thick skinned" model for the High Atlas Mountains (Morocco). Implications for the structural inheritance of the southern Tethys passive margin. Journal of Structural Geology, 28(11), 19581976.

Flemings, P.B., Jordan, T.E., 1990. Stratigraphic modeling of foreland basins: Interpreting thrust deformation and lithosphere rheology. Geology, 18(5), 430434.

Flugel, E., 2004. Microfacies of carbonate rocks: analysis, interpretation and application. Springer.

Fraissinet, C., El Zouine, M., Morel, J.L., Poisson, A., Andrieux, J., Faure-Muret, A., 1988. Structural evolution of the southern and northern central High Atlas in Paleogene and Mio-Pliocene times. In: The Atlas System of Morocco. Springer Berlin Heidelberg, $273-291$. 
Freytet, P., 1971. Paléosols résiduels et paléosols alluviaux hydromorphes dans le Crétacé supérieur et l'Eocène basal en Languedoc. Revue Géography Physic Géologie Dynamique. XIII: 245-268.

Freytet, P., 1973. Petrography and paleo-environment of continental carbonate deposits with particular reference to the Upper Cretaceous and Lower Eocene of Languedoc (Southern France). Sedimentary Geology, 10(1), 25-60.

Freytet, P., 1984. Les sédiments lacustres carbonatés et leur transformation par émersion et pédogénèse. Importance de leur identification pour les reconstitutions paléogéographiques. Bulletin des Centres de Recherche et Exploration-Production Elf-Aquitaine, 8: 223-247.

Freytet, P., Verrecchia, E.P., 2002. Lacustrine and palustrine carbonate petrography: an overview. Journal of Paleolimnology, 27(2), 221-237.

Fraissinet, de F., Saint Bezar, B., Bracène, R., Mercier, E., 2000. The two main steps of the Atlas building and geodynamics of the western Mediterranean. Tectonics, 19(4), 740-761.

Frizon de Lamotte, D., Saint Bezar, B., Bracène, R.,Mercier, E., 2000. The two main steps of the Atlas building and geodynamics of the western Mediterranean. Tectonics, 19(4), 740-761.

Frizon de Lamotte, D., Leturmy, P., Missenard, Y., Khomsi, S., Ruiz, G., Saddiqi, O., Guillocheau, F.,Michard, A. 2009. Mesozoic and Cenozoic vertical movements in the Atlas system (Algeria, Morocco, Tunisia): An overview. Tectonophysics, 475(1), 9-28.

Görler, K., Helmdach, F.F., Gaemers, P., Heissig, K., Hinsch, W., Mädler, K., Shwarzhans, W., Zucht, M., 1988. The uplift of the central High Atlas as deduced 
from Neogene continental sediments of the Ouarzazate province, Morocco. Lecture Notes in Earth Science,15, 363-404.

Gomez, F., Beauchamp, W., Barazangi, M., 2000. Role of the Atlas Mountains (northwest Africa) within the African-Eurasian plate-boundary zone. Geology, 28(9), 775-778.

Goudie, A.S., 1996. Organic agency in calcrete development. Journal of Arid Environments, 32(2), pp.103-110.

Gradstein, F. M., Ogg, J. G., Schmitz, M., Ogg, G. (Eds.). 2012. The geologic time scale 2012. Elsevier, New York. Accessed through the Timescale Creator website https://engineering.purdue.edu/Stratigraphy/tscreator/index/index.php.

Heller, P.L., Angevine, C.L., Winslow, N.S., Paola, C., 1988. Two-phase stratigraphic model of foreland-basin sequences. Geology, 16(6), 501-504.

Herdendorf, C.E., 1984. Inventory of the morphometric and limnologic characteristics of the large lakes of the world. The Ohio State University Sea Grant Program, Technical Bulletin OHSU-TB-17, 78 p.

Jacobshagen, V., Görler, K., Giese, P., 1988. Geodynamic evolution of the Atlas System (Morocco) in post-Palaeozoic times. In: The Atlas System of Morocco. Springer Berlin Heidelberg, 481-499.

Jaeger, J-J., 1977. Les Rongeurs du Miocène moyen et supérieur du Maghreb. Palaeovertebrata, 8 (1), 1-166

Keith, M.L., Weber, J.N., 1964. Carbon and oxygen isotopic composition of selected limestones and fossils. Geochimica et Cosmochimica Acta, 28(10),1787-1816. Leprêtre, R., Missenard, Y., Saint-Bezar, B., Barbarand, J., Delpech, G., Yans, J., Dekoninck, A., Saddiqi, O., 2015. The three main steps of the Marrakech High 
Atlas building in Morocco: Structural evidences from the southern foreland, Imini area, Journal of African Earth Sciences. Pergamon, 109, 177-194.

Marr, J. G., Swenson, J. B., Paola, C., Voller, V. R., 2000. A two-diffusion model of fluvial stratigraphy in closed depositional basins. Basin Research, 12(3-4), 381398.

Missenard, Y., Zeyen, H., de Lamotte, D. F., Leturmy, P., Petit, C., Sébrier, M., Saddiqi, O., 2006. Crustal versus asthenospheric origin of relief of the Atlas mountains of Morocco, Journal of Geophysical Research: Solid Earth, 111(3), 113.

Parsons, A.J., Michael, N.A., Whittaker, A.C., Duller, R.A., Allen, P.A., 2012. Grain size trends reveal the late orogenic tectonic and erosional history of the south central Pyrenees, Spain. Journal of the Geological Society, London, 169, 111114.

Pastor, À., Teixell, A., Arboleya, M.L., 2012. Rates of quaternary deformation in the ouarzazate basin (southern atlas front, Morocco). Annals of Geophysics, 55(5), 1003-1016.

Pietras, J.T., Carroll, A.R., Rhodes, M.K., 2003. Tectonic control on lacustrine evaporite deposition in the Eocene Green River Formation. Wyoming. Journal of Paleolimnology, 70, 115-125.

Platt, N. H., Wright, V.P., 1991. Lacustrine carbonates: facies models, facies distribution and hydrocarbon aspects. In: Anadon, P., L. Cabrera \& K. Kelts (eds), Lacustrine Facies Analysis. IAS special publication 13. Blackwell, Oxford, 57-74. 
Platt, N.H., Wright, V.P., 1992. Palustrine Carbonates and the Florida Everglades: towards an exposure index for the fresh-water environment? Journal of Sedimentary Research, 62(6), 1058-1071.

Pla-Pueyo, S., Gierlowski-Kordesch, E.H., Viseras, C., Soria, J.M., 2009. Major controls on sedimentation during the evolution of a continental basin: PliocenePleistocene of the Guadix Basin (Betic Cordillera, southern Spain). Sedimentary Geology, 219(1-4), 97-114.

Potter, P.E., Szatmari, P., 2009. Global Miocene tectonics and the modern world. Earth Science Reviews, 96(4), 279-295.

Remy, J-A., Benammi, M., 2006. Presence of a Gomphotheriidea indet. (Proboscidea, Mammalia) in the Vallesian fauna of Afoud AF6 (Aït Kandoula Basin, Morocco), inferred from the enamel microstructure of a molar chip. Geobios, 555-562.

Roehler, H.W., 1993. Eocene climates, depositional environments, and geography, greater Green River Basin, Wyoming, Utah, and Colorado. United States Geological Survey, Professional Paper, (1506-F).

Sáez, A., Anadón, P., Herrero, M.J., Moscariello, A., 2007. Variable style of transition between Palaeogene fluvial fan and lacustrine systems, southern Pyrenean foreland, NE Spain. Sedimentology, 54(2), 367-390.

Schuster, M., Duringer, P., Ghienne, J.F., Vignaud, P., Mackaye, H.T., Likius, A., Brunet, M., 2006. The age of the Sahara desert. Science, 311, 821-821.

Sepulchre, P., Ramstein, G., Fluteau, F., Schuster, M., Tiercelin, J.J., Brunet, M., 2006. Tectonic uplift and Eastern Africa aridification. Science, 313, 1419-1423. 
Stäblein, G., 1988. Geomorphological aspects of the Quaternary evolution of the Ouarzazate Basin, Southern Morocco: Lecture Notes in Earth Sciences, 15, 433-443.

Stokes, M., Mather, A. E., Belfoul, A., Farik, F., 2008. Active and passive tectonic controls for transverse drainage and river gorge development in a collisional mountain belt (Dades Gorges, High Atlas Mountains, Morocco), Geomorphology, 102(1), 2-20.

Stokes, M., Mather, A. E., Belfoul, M., Faik, F., Bouzid, S., Geach, M. R., Cunha, P. P., Boulton, S. J., Thiel, C. 2017. Controls on dryland mountain landscape development along the NW Saharan desert margin: Insights from Quaternary river terrace sequences (Dadès River, south-central High Atlas, Morocco), Quaternary Science Reviews, 166, 363, 379.

Talbot, M.R., 1990. A review of the palaeohydrological interpretation of carbon and oxygen isotopic ratios in primary lacustrine carbonates. Chemical Geology, $80(4), 261-279$.

Talbot, M. R., Kelts, K., 1990. Paleolimnological Signatures from Carbon and Oxygen Isotopic Ratios in Carbonates. In: B.J. Katz, B.R. Rosendahl (Eds)., Lacustrine Basin Exploration: Case Studies and Modern Analogs. AAPG Special Volume, M50, 99-112.

Tanner, L.H., 2000. Miocene-Pliocene Lacustrine and Marginal Lacustrine Sequences of the Furnace Creek Formation, Furnace Creek and Central Death Valley Basins, Death Valley Region, USA. AAPG Studies in Geology\# 46, Chapter 44 481-489. 
Teson, E., Teixell, A., 2008. Sequence of thrusting and syntectonic sedimentation in the eastern sub-Atlas thrust belt (Dades and Mgoun valleys, Morocco). International Journal of Earth Science, 97, 103-113.

Teson, E., Puyoe, E.L., Teixell, A., Barnolas, A., Agusti, J., Furio, M., 2010. Magnetostratigraphy of the Ouarzazte Basin: Implications for the timing of deformation and mountain building in the High Atlas Mountains of Morocco. Geodinamica Acta, 23, 151-165.

Valero-Garcés, B.L., Aguilar, J.G., 1992. Shallow carbonate lacustrine facies models in the Permian of the Aragon-Bearn basin (Western Spanish-French Pyrenees). Carbonates Evaporites, 7(2), 94-107.

Valero-Garcés, B.L., Kelts, K., Ito, E., 1995. Oxygen and carbon isotope trends and sedimentological evolution of a meromictic and saline lacustrine system: the Holocene Medicine Lake basin, North American Great Plains, USA. Palaeogeography, Palaeoclimatology, Palaeoecology, 117(3), 253-278.

Whittaker, A.C., Duller, R.A., Springett, J., Smithells, R., Whitchurch, A.L., Allen, P.A., 2011. Decoding downstream trends in stratigraphic grain $\square$ size as a function of tectonic subsidence and sediment supply. Bulletin of the Geological Society America, 123, 1363-1382.

Wright, V.P., 1990. A micromorphological classification of fossil and recent calcic and petrocalcic microstructures. Developments in soil science, 19, 401-407. Wright, V.P., Platt, N.H., 1995. Seasonal wetland carbonate sequences and dynamic catenas: a re-appraisal of palustrine limestones. Sedimentary Geology, 99(2), $65-71$. 
Wright, V.P., Platt, N.H., Marriott, S.B., Beck, V.H., 1995. A classification of

rhizogenic (root-formed) calcretes, with examples from the Upper Jurassic-Lower Cretaceous of Spain and Upper Cretaceous of southern France. Sedimentary Geology, 100(1), 143-158.

Zouhri, S., Geraads, D., El Boughabi, S., El Harfi, A., 2012. Discovery of an Upper Miocene Vertebrate fauna near Tizi N'Tadderht, Skoura, Ouarzazate Basin (Central High Atlas, Morocco), Comptes Rendus Palevol. 11(6), 455-461.

\begin{tabular}{|c|c|c|c|c|c|}
\hline $\begin{array}{l}\text { Facies } \\
\text { code }\end{array}$ & & Facies Name & Description & Process & Interpretation \\
\hline $\mathrm{Mp}$ & 1 & Mottled mudstone & $\begin{array}{l}\text { Red to grey/white } \\
\text { mottled mudstones, } \\
\text { occasionally gypsiferous, } \\
\text { occasional caliche } \\
\text { nodules and root traces. }\end{array}$ & Soil formation & $\begin{array}{l}\text { Paleosols } \\
\text { forming in flood } \\
\text { plain or marginal } \\
\text { lacustrine } \\
\text { environments. }\end{array}$ \\
\hline M & 2 & Mudstone & $\begin{array}{l}\text { Thin beds }(<5 \mathrm{~cm}) \text { of } \\
\text { dark grey to black } \\
\text { mudstone, rich in } \\
\text { microfossil material. }\end{array}$ & $\begin{array}{l}\text { Settling from } \\
\text { suspension, low } \\
\text { oxygen } \\
\text { conditions }\end{array}$ & Basin deposition \\
\hline Мa & 3 & Marl & $\begin{array}{l}\text { Thick beds of massive } \\
\text { light grey marl, variable } \\
\text { fossil content, locally } \\
\text { gypsiferous. }\end{array}$ & $\begin{array}{l}\text { Settling from } \\
\text { suspension }\end{array}$ & Basin deposition \\
\hline Sp & 4 & $\begin{array}{l}\text { Planar laminated } \\
\text { sandstone }\end{array}$ & $\begin{array}{l}\text { Very coarse-grained to } \\
\text { granular litharenite with } \\
\text { planar laminations. } \\
\text { Bedding planes are sharp } \\
\text { and beds are } 0.25-0.5 \mathrm{~m} \\
\text { thick. }\end{array}$ & $\begin{array}{l}\text { Upper flow } \\
\text { regime laminar } \\
\text { flow }\end{array}$ & Flood deposition \\
\hline Sch & 5 & $\begin{array}{l}\text { Channelised } \\
\text { granular to pebbly } \\
\text { sandstones }\end{array}$ & $\begin{array}{l}\text { Granular to pebbly } \\
\text { litharenites, generally } \\
\text { have sharp, erosional } \\
\text { bases forming wide and } \\
\text { shallow channel } \\
\text { structures. }\end{array}$ & $\begin{array}{l}\text { Sediment } \\
\text { infilling channel } \\
\text { scours }\end{array}$ & $\begin{array}{l}\text { Small fluvial } \\
\text { channels. }\end{array}$ \\
\hline Gy & 6 & Selenite Gypsum & $\begin{array}{l}\text { Selenite gypsum crystals } \\
\text { up to } 5 \mathrm{~cm} \text { in length }\end{array}$ & $\begin{array}{l}\text { Subaqueous } \\
\text { crystallisation } \\
\text { from brine }\end{array}$ & $\begin{array}{l}\text { Evaporitic } \\
\text { conditions }\end{array}$ \\
\hline Gf & 7 & Fibrous Gypsum & & & \\
\hline Sg & 8 & Gypsarenite & $\begin{array}{l}\text { White, very fine-grained, } \\
\text { well sorted gypsum } \\
\text { sandstone. }\end{array}$ & $\begin{array}{l}\text { Accumulation } \\
\text { of detrital } \\
\text { gypsum }\end{array}$ & $\begin{array}{l}\text { Evaporiate } \\
\text { shaol/flat }\end{array}$ \\
\hline
\end{tabular}




\begin{tabular}{|c|c|c|c|c|c|}
\hline $\mathrm{Gg}$ & 9 & $\begin{array}{l}\text { Gypsiferous } \\
\text { conglomerate }\end{array}$ & $\begin{array}{l}\text { Matrix supported } \\
\text { conglomerate formed of } \\
\text { selenite crystals up to } 30 \\
\text { cm in length in a pink - } \\
\text { red lime mudstone } \\
\text { matrix. }\end{array}$ & Debris flow & $\begin{array}{l}\text { Downslope } \\
\text { transport. }\end{array}$ \\
\hline Gc & 10 & $\begin{array}{l}\text { Clast-supported } \\
\text { conglomerate }\end{array}$ & $\begin{array}{l}\text { Clast-supported } \\
\text { conglomerate with sub- } \\
\text { angular to rounded, } \\
\text { poorly sorted clasts of } \\
\text { various lithologies. Beds } \\
\text { are laterally continuous } \\
\text { with sharp, locally } \\
\text { erosional bases. }\end{array}$ & Sheet flood & $\begin{array}{l}\text { Distal alluvial } \\
\text { fan }\end{array}$ \\
\hline $\mathrm{LM}$ & 11 & Carbonates & $\begin{array}{l}\text { Thinly bedded mudstones } \\
\text { and packstones with } \\
\text { gastropods and bioclastic } \\
\text { fragments. Beds are } \\
\text { sharp and often laterally } \\
\text { discontinuous. } \\
\text { Bioturbation is common, } \\
\text { where absent algal } \\
\text { laminations are present. }\end{array}$ & $\begin{array}{l}\text { Settling from } \\
\text { suspension or } \\
\text { accumulation in } \\
\text { algal mats. } \\
\text { Subsequent } \\
\text { pedogenic } \\
\text { alteration }\end{array}$ & Lacustrine \\
\hline
\end{tabular}

Table 1. Summary of sedimentary facies

\begin{tabular}{|c|c|c|c|c|}
\hline \multicolumn{2}{|l|}{ Section 01} & \multirow[b]{2}{*}{$d^{18} \mathrm{O}$} & \multirow[b]{2}{*}{$\begin{array}{l}\text { Section height } \\
\text { (m) }\end{array}$} & \multirow[b]{2}{*}{ Facies } \\
\hline Sample ID & $d^{13} C$ & & & \\
\hline MR0101 & -5.83 & \begin{tabular}{|l|}
-7.32 \\
\end{tabular} & 10.35 & 1 \\
\hline MR0103 & -5.84 & -8.35 & 49.95 & 1 \\
\hline MR0104A & -6.58 & \begin{tabular}{|l|}
-8.10 \\
\end{tabular} & 50.65 & 2 \\
\hline MR0104B & -6.65 & -6.91 & 50.65 & 2 \\
\hline MR0105 & -6.00 & \begin{tabular}{|l|}
-7.66 \\
\end{tabular} & 60.65 & 2 \\
\hline MR0106 & -6.14 & \begin{tabular}{|l|}
-7.76 \\
\end{tabular} & 61.15 & 2 \\
\hline MR0107 & -5.93 & \begin{tabular}{|l|}
-7.74 \\
\end{tabular} & 61.65 & 2 \\
\hline MR0108A & -6.42 & \begin{tabular}{|l|}
-7.79 \\
\end{tabular} & 65.65 & 2 \\
\hline MR0108B & -6.44 & -7.80 & 65.65 & 2 \\
\hline MR0109 & -5.96 & \begin{tabular}{|l|}
-7.57 \\
\end{tabular} & 66.55 & 2 \\
\hline MR0110 & -6.63 & -8.65 & 67.05 & 2 \\
\hline MR0111 & -6.49 & \begin{tabular}{|l|}
-7.89 \\
\end{tabular} & 69.75 & 1 \\
\hline MR0112 & -6.97 & -7.93 & 75.1 & 2 \\
\hline
\end{tabular}




\begin{tabular}{|c|c|c|c|c|}
\hline MR0113 & -6.81 & -7.98 & 80.4 & 2 \\
\hline MR0114 & -6.55 & -7.92 & 80.85 & 2 \\
\hline MR0115 & -6.21 & -8.54 & 82.85 & 2 \\
\hline MR0116 & -6.31 & -8.44 & 87.75 & 2 \\
\hline MR0117A & -6.19 & -8.79 & 90.45 & 1 \\
\hline MR0117B & -6.43 & -8.89 & 90.45 & 1 \\
\hline MR0118A & -6.40 & -8.31 & 91.45 & 1 \\
\hline MR0118B & -6.81 & -8.62 & 91.45 & 1 \\
\hline MR0119 & -6.82 & -8.01 & 95.05 & 1 \\
\hline MR0120 & -7.28 & -8.93 & 96.75 & 2 \\
\hline MR0121 & -6.92 & -8.34 & 97.95 & 2 \\
\hline MR0122 & -6.03 & -7.89 & 102.45 & 2 \\
\hline MR0123 & -5.88 & -7.62 & 103.25 & 2 \\
\hline \multicolumn{5}{|l|}{ Section 02} \\
\hline MR0201 & -4.61 & -7.19 & 4.50 & 1 \\
\hline MR0202 & -5.73 & -8.17 & 5.00 & 1 \\
\hline MR0203 & -5.66 & -8.71 & 5.25 & 1 \\
\hline MR0205 & -8.12 & -9.63 & 7.80 & 1 \\
\hline MR0206 & -5.18 & -7.89 & 78.84 & 1 \\
\hline MR0209 & -5.61 & -8.01 & 204.79 & 1 \\
\hline MR0211 & -4.14 & -5.16 & 355.18 & 1 \\
\hline MR0212 & -6.39 & -8.78 & 357.48 & 1 \\
\hline \multicolumn{5}{|l|}{ Section 04} \\
\hline MR4A01 & -4.92 & 1.17 & 0.90 & 1 \\
\hline MR4A04 & -6.27 & -4.00 & 2.40 & 3 \\
\hline MR4A05 & -5.70 & -6.61 & 2.60 & 3 \\
\hline MR0402 & -5.55 & -5.76 & 4.30 & 1 \\
\hline MR0403 & -5.54 & -6.21 & 4.70 & 1 \\
\hline MR0404 & -5.83 & -6.70 & 5.40 & 1 \\
\hline MR0405 & -5.50 & -6.45 & 5.70 & 1 \\
\hline MR0406 & -4.93 & -6.33 & 6.00 & 1 \\
\hline MR0407 & -5.97 & -6.02 & 8.80 & 1 \\
\hline MR0408 & -6.68 & -5.90 & 9.10 & 1 \\
\hline MR0409 & -6.41 & -5.40 & 9.22 & 1 \\
\hline MR0410 & -5.77 & -5.70 & 9.67 & 1 \\
\hline
\end{tabular}




\begin{tabular}{|c|c|c|c|c|}
\hline MR0411 & -4.99 & -3.81 & 9.82 & 1 \\
\hline MR0414 & -7.57 & -6.54 & 11.72 & 1 \\
\hline MR0415 & -6.11 & -6.18 & 13.97 & 3 \\
\hline MR0416 & -5.46 & -6.39 & 14.17 & 3 \\
\hline MR0419 & -6.87 & -6.98 & 25.32 & 1 \\
\hline MR0420 & -7.65 & -6.83 & 26.72 & 3 \\
\hline MR0422 & -7.69 & -8.17 & 27.02 & 1 \\
\hline MR0424 & -7.01 & -7.57 & 27.57 & 1 \\
\hline MR0425 & -5.45 & -8.36 & 35.32 & 1 \\
\hline MR0426 & -5.83 & -6.45 & 39.42 & 3 \\
\hline MR0427 & -6.07 & -6.08 & 40.52 & 1 \\
\hline MR0428 & -5.48 & -5.92 & 41.27 & 1 \\
\hline MR0430 & -5.71 & -6.98 & 51.52 & 1 \\
\hline MR0431 & -5.46 & -7.77 & 51.82 & 1 \\
\hline \multicolumn{5}{|l|}{ Section 05} \\
\hline MR0502 & -3.03 & -7.59 & 4.7 & 1 \\
\hline MR0503 & -3.92 & -7.92 & 8.75 & 1 \\
\hline MR0504 & -3.55 & -8.42 & 9.25 & 1 \\
\hline MR0505 & -3.51 & -5.87 & 12.55 & 1 \\
\hline MR5A02 & -4.56 & -8.26 & 45 & 1 \\
\hline MR5A03 & -4.39 & -7.39 & 45.25 & 1 \\
\hline \multicolumn{5}{|l|}{ Section 06} \\
\hline MR0601A & -5.02 & -3.73 & 12 & 1 \\
\hline MR0601B & -4.17 & -3.70 & 12 & 1 \\
\hline MR0602 & -5.20 & -2.81 & 20.5 & 1 \\
\hline MR0603 & -5.16 & -3.36 & 25 & 1 \\
\hline MR0604 & -4.39 & -1.91 & 54.25 & 1 \\
\hline MR0605 & -4.02 & -1.96 & 54.75 & $1 a$ \\
\hline MR0606 & -4.47 & -2.11 & 55.75 & 1 \\
\hline MR0607 & -5.24 & -4.65 & 56.25 & 1 \\
\hline MR0608 & -5.16 & -4.06 & 56.75 & 1 \\
\hline MR0609 & -5.09 & -3.20 & 57.25 & 1 \\
\hline MR0610 & -5.59 & -4.34 & 57.75 & 1 \\
\hline MR0611 & -4.39 & -3.20 & 58.25 & $1 a$ \\
\hline MR0612 & -4.79 & -4.38 & 58.75 & $1 a$ \\
\hline
\end{tabular}




\begin{tabular}{|c|c|c|c|c|}
\hline MR0613 & -4.61 & -3.21 & 59.25 & $1 a$ \\
\hline MR0614 & -5.48 & -3.69 & 59.75 & $1 a$ \\
\hline MR0615 & -6.72 & -6.12 & 61.5 & 1 \\
\hline MR0616 & -6.57 & -6.04 & 68.25 & 1 \\
\hline MR0617 & -5.89 & -5.12 & 68.75 & 1 \\
\hline MR0618 & -6.85 & -5.55 & 69.25 & 1 \\
\hline MR0619 & -6.84 & -6.48 & 69.5 & $1 a$ \\
\hline MR0620 & -5.98 & -4.90 & 73 & $1 a$ \\
\hline MR0621 & -5.59 & -2.47 & 76.5 & 1 \\
\hline MR0622 & -6.08 & -5.98 & 80 & 1 \\
\hline MR0623 & -7.38 & -7.36 & 80.5 & $1 a$ \\
\hline MR0624 & -7.71 & -7.60 & 81.5 & 1 \\
\hline MR0625 & -6.09 & -6.48 & 83 & 1 \\
\hline MR0626A & -6.19 & -7.27 & 83.5 & 1 \\
\hline MR0626B & -5.99 & -6.89 & 83.5 & 1 \\
\hline MR0627 & -6.77 & -7.06 & 84.5 & 1 \\
\hline MR0628 & -6.57 & -7.16 & 85 & 1 \\
\hline MR0629 & -6.80 & -7.99 & 87.25 & 1 \\
\hline MR0630 & -7.09 & -7.43 & 88 & 1 \\
\hline MR0631 & -6.99 & -7.46 & 88.75 & 1 \\
\hline MR0633 & -6.61 & -6.72 & 91.5 & 1 \\
\hline MR0634 & -3.07 & -6.51 & 92.75 & 2 \\
\hline MR0635 & -5.93 & -6.52 & 97 & 2 \\
\hline MR0636 & -6.62 & -7.18 & 98.25 & 2 \\
\hline MR0637 & -6.15 & -8.35 & 102.75 & 2 \\
\hline MR0638 & -6.67 & -8.25 & 103.75 & 2 \\
\hline MR0639 & -5.74 & -7.54 & 104.1 & 1 \\
\hline MR0640 & -5.06 & -6.73 & 104.15 & 2 \\
\hline MR0641 & -6.13 & -7.24 & 104.7 & 2 \\
\hline MR0642 & -5.87 & -7.52 & 105.05 & 2 \\
\hline MR0643 & -5.44 & -7.70 & 105.2 & 2 \\
\hline MR0644 & -5.76 & -7.11 & 105.3 & 2 \\
\hline MR0645 & -5.53 & -6.80 & 105.7 & 2 \\
\hline MR0646 & -6.21 & -7.95 & 106.2 & 2 \\
\hline MR0647 & -4.29 & -4.12 & 127.8 & 1 \\
\hline
\end{tabular}




\begin{tabular}{|l|l|l|l|l|}
\hline MR0648 & -5.17 & -1.18 & 129.3 & 1 \\
\hline MR0649 & -2.12 & -2.34 & 132.95 & 1 \\
\hline MR0650 & -5.82 & -8.27 & 146.2 & 1 \\
\hline MR0652 & -5.84 & -8.93 & 151.45 & 1 \\
\hline MR0653 & -4.47 & -8.51 & 152.2 & 1 \\
\hline MR0654 & -5.47 & -8.38 & 157.2 & 1 \\
\hline
\end{tabular}

Table 2. Carbonate $\delta^{18} \mathrm{O}$ and $\delta^{13} \mathrm{C}$ isotope data from each measured section. Facies codes are: 1) Lime mudstone; 1a) Lime mudstone with little evidence of pedogenic alteration; 2) wackestone. 